\title{
Reformation and Reallocation: Religious and Secular Economic Activity in Early Modern Germany
}

\author{
Davide Cantoni \\ Jeremiah Dittmar \\ Noam Yuchtman
}

CESIFO WORKING PAPER NO. 6218

CATEgORy 6: Fiscal Policy, MaCROECONOMICS AND GROWTH

NOVEMBER 2016

An electronic version of the paper may be downloaded

- from the SSRN website:

- from the RePEc website:

- from the CESifo website:

WWw.SSRN.com

www.RePEc.org

www.CESifo-group.org/wp 


\title{
Reformation and Reallocation: Religious and Secular Economic Activity in Early Modern Germany
}

\begin{abstract}
The Protestant Reformation, beginning in 1517, was a first-order economic shock. We document its effects on the sectoral allocation of economic activity in Germany using highly disaggregated data. During the Reformation, particularly in Protestant regions, large numbers of monasteries were expropriated. University graduates shifted toward secular, rather than religious, occupations. Forward-looking university students shifted away from the study of religious sector-specific theology, toward secular fields. Construction activity in the religious sector declined, particularly in Protestant regions, while secular construction increased. These findings highlight the unintended consequences of the Reformation-a religious movement that contributed to Europe's secularization.
\end{abstract}

JEL-Codes: N130, N330, J240, E020.

Keywords: protestant reformation, sectoral allocation, human capital.

\author{
Davide Cantoni \\ University of Munich \\ Munich / Germany \\ cantoni@lmu.de
}

Jeremiah Dittmar

London School of Economics

London / United Kingdom

j.e.dittmar@lse.ac.uk
Noam Yuchtman

UC-Berkeley, Haas School of Business

Berkeley / California / USA

yuchtman@haas.berkeley.edu

November 2016

Helpful and much appreciated suggestions, critiques and encouragement were provided by Ernesto Dal Bó, Matt Notowidigdo, Yona Rubinstein, Jan Luiten van Zanden, and seminar participants at Bonn, Harvard, LSE, NYU Stern, UC Davis, Utrecht, the AEA meetings, the DAE meeting at the NBER Summer Institute, the RES meeting, the University of California GEM-BPP ResearchWorkshop, the University of Munich Conference on the Long Shadow of History, and theWorld Economic History Congress. Excellent research assistance was provided by Julia Bewerunge, Tillmann von Carnap, Florian Döbler, Nikolaus Drax, Russell Gasdia, Max Höfl, Selina Hofstetter, Carolin Maier, Matthias Mall, Daniela Miehling, and Skipper Seabold. Cantoni acknowledges research support from the Marie Curie Integration Grant. Dittmar acknowledges research support from the European Research Council. The authors have no conflict of interest, financial or otherwise, related to this study. 


\section{Introduction}

The Catholic Church in medieval and early modern Europe enjoyed a monopoly over organized religion that conferred political and economic power and made it the most important institution in the Western world. The Protestant Reformation of 1517 marked a historic break, presenting an ideological challenge to the Catholic Church's authority. This monumental event in Western history has, unsurprisingly, received a great deal of scholarly attention: a massive literature in the historical social sciences examines the Reformation as a social, political, and cultural event (e.g., Weber, 1904/05; Ozment, 1980; Witte, 2002; Berman, 2003), and a growing literature in economics studies the impact of the Protestant Reformation over subsequent centuries (e.g., Guiso et al., 2003; Becker and Woessmann, 2009; Basten and Betz, 2013; Cantoni, 2015; Spenkuch, 2016; Dittmar and Meisenzahl, 2016). Yet, remarkably little work exists on the immediate economic consequences of the Reformation in the early modern era. In this article, we present quantitative evidence on the Reformation as an enormous economic shock. We document its first-order consequences for the sectoral allocation of economic activity in early modern Europe, interpreting these changes through a framework emphasizing the Reformation's effects on Europe's political economy and labor markets.

We assemble new, highly disaggregated data that allow us to examine the reallocation of economic resources between the religious sector (whether Catholic or Protestant) and the secular sector, in Germany, in the decades following Luther's posting of his 95 theses in $1517 .{ }^{1}$ We collect data on the sectoral allocation of all of the major inputs in a macroeconomic production function: land, capital, and human capital. We first present data on the closure of monasteries across Germany: monastery closure directly reallocated land and capital from church uses to the possession of secular rulers. Monastery closure also led to the reallocation of human capital, both directly and indirectly. To study the sectoral allocation of labor more closely, we next document the allocation of human capital between the religious and secular sectors using individual-level data on the universe of German university graduates between 1475 and 1600. We examine both the sector of graduates' occupations, and whether the human capital they acquired was specific to the religious sector (theology) or more general. Finally, we consider major construction events: these can be seen as summary statistics for the allocation of resources, embodying bundles of land and physical, financial, and human capital. We observe construction events by sector-religious and

\footnotetext{
1 "Religious sector" and "secular sector" are imperfect, but concise, terms for activities in a society that was permeated by religiosity. To be clear, we use the term "religious" to describe actions that were primarily oriented toward religious observance: for example, the construction of a church; taking a position as a monk or priest; or, the study of theology, which almost invariably led to a job as a monk, priest, etc. In contrast, we use the term "secular" to describe actions that were not primarily oriented toward religious observance: for example, constructing a hospital, merchant hall, or palace; taking a position in a secular lord's public administration; or studying law. The "secular sector" of the economy thus included many religious individuals and even involved religious institutions (Catholic and Protestant), but was oriented toward different immediate aims from the "religious sector". "Germany", too, is an anachronistic term. To be precise, we study the German-speaking lands of the Holy Roman Empire. For concision, we use the term "Germany" throughout the text.
} 


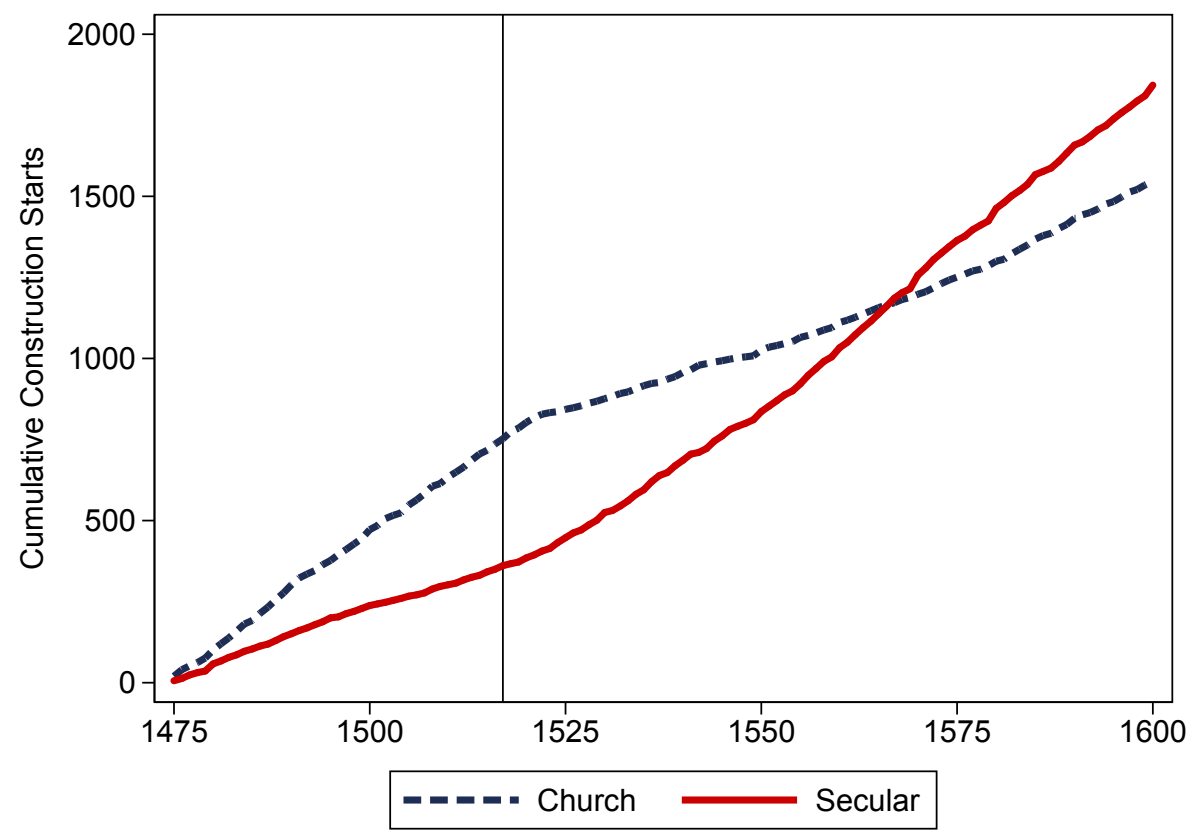

Figure 1: Cumulative number of new construction events in the religious and secular sectors in Germany. Data come from the Deutsches Städtebuch.

secular-at the town-by-year level, across over 2,000 German towns.

As a first approach to our data, we examine new construction activity in the church and secular sectors across all of Germany. In Figure 1, one can see a striking pivot from rapid church sector construction to rapid secular sector construction precisely at the time of the Reformation. This observed shift toward secular activity in the construction time series-with no indication of a pre-Reformation shift in economic activity-motivates us to examine both time series and crosssectional variation in resource allocation across multiple margins.

Our analysis yields four facts. First, we document the large-scale closure of monasteries after 1517, indicating a dramatic decline in the religious sector's control of land, capital, and labor across Germany. This decline was particularly pronounced in regions that adopted Protestantism. We observe few closures of monasteries prior to 1517, and no pre-Reformation differential trends in the closure of monasteries between territories that would eventually become Protestant and those that would remain Catholic. These patterns are consistent with the Reformation playing a causal role in driving the decline of monasteries, resulting in the direct transfer of land and capital into the control of secular authorities, lords and cities.

Second, following the Reformation, university graduates from Protestant universities shifted toward entering secular occupations, rather than religious ones (e.g., city councillors or gold- 
smiths, rather than priests or monks). ${ }^{2}$ While there is some evidence of a pre-Reformation trend toward secular occupations, we find no pre-Reformation differences in occupational choice trends between universities that would become Protestant and those that would remain Catholic. Nor do we find a sectoral shift in occupations among graduates from Catholic universities following the Reformation. These patterns are consistent with the Reformation playing a causal role in driving the differential change in occupational choices. They reflect the reduced demand for human capital in the religious sector resulting from the closure of monasteries, as well as increased labor demand from more powerful secular lords, particularly in the territories that adopted the Reformation. ${ }^{3}$

Third, immediately after the beginning of the Reformation individuals at Protestant universities reallocated their human capital investments away from religious sector-specific theology degrees, and toward the study of more general, secular subjects. This is precisely what one would expect from forward-looking students observing reduced labor demand and greater uncertainty in the religious sector. The data are again consistent with the Reformation playing a causal role in driving the changed human capital investments: we do not observe pre-Reformation declines in the study of theology or pre-Reformation differences in degrees granted between universities that would become Protestant and those that would remain Catholic. The changed nature of human capital investments in Protestant territories following the Reformation supported the reallocation of upper tail human capital away from religious occupations, and toward secular ones. ${ }^{4}$

Fourth, following the Reformation, new construction events shifted from religious purposes toward secular ones (e.g., from churches to merchants' halls) across Germany, as seen in Figure 1. We further find that this sectoral reallocation occurred differentially more in Protestant territories. Again, the evidence is consistent with the Reformation playing a causal role: we find no evidence of a pre-Reformation shift toward secular construction, or of differential pre-Reformation trends in construction between Catholic and Protestant territories. The construction data indicate that broad bundles of economic inputs—land, labor, and capital—were all reallocated toward secular uses following the Reformation.

The data we collect thus reveal a sharp reallocation of resources toward secular purposesnot simply a reallocation from Catholic to Protestant churches. We document that, under rulers

\footnotetext{
${ }^{2}$ Particularly in light of Protestant attacks on Catholic Church corruption, this result calls to mind of work by Murphy et al. (1991), who study the allocation of talent between a rent-seeking and productive sector. We focus here on documenting the reallocation of resources across sectors, leaving the study of efficiency or productivity consequences to future work.

${ }^{3}$ Sectoral shifts in occupational choice may also reflect changes in labor supply. The question of why particular territorial lords adopted the Protestant religion is an important one, addressed in Cantoni (2012). Our findings of parallel pre-Reformation trends, both in human capital investments and other economic variables, discussed below, suggest that the sources of variation in adoption were generally not associated with our outcomes of interest prior to the Reformation.

${ }^{4}$ The important roles played by human capital elites in European history have been explored by Mokyr (2009); Cantoni and Yuchtman (2014); Squicciarini and Voigtländer (2015); Dittmar and Meisenzahl (2016). We build on their work by discussing a specific source of variation in university students' selection into fields of study and careers.
} 
who were personally religious and in settings where the development of state capacity reflected religious ideas, the Reformation produced an economic secularization that was remarkably rapid, and most pronounced in regions that adopted the Protestant religion.

The shift in resources away from religious uses that we document is surprising. The Protestant Reformation was a religious revival movement that aimed to elevate the role of religion in society and indeed generated a rise in cultural religiosity. Moreover, considering the Reformation in economic terms as an increase in competition in the market for religion, one might have expected an increase in the consumption of religious services (Iannaccone, 1998; Ekelund et al., 2006). Our evidence thus poses a puzzle: how did this fundamentally religious movement lead to (economic) secularization?

We argue that the answer lies in the unintended effects of religious competition on the political economy and labor markets of early modern Europe. Competition in the religious sector created an opening for secular lords to expropriate monastic property and to increase their control of public administration, thus expanding their demand for highly-skilled labor. The decline of monasteries reduced the demand for university graduates in theology. Forward-looking university students thus shifted toward training in secular subjects and careers in secular occupations. ${ }^{5}$ More broadly, the increased power of the secular authorities, along with resources confiscated from the Catholic Church, led to a more general re-allocation of resources away from church uses and toward uses favored by secular elites. This is reflected in the sectoral composition of construction activity.

Our analysis contributes to the large literature on the economic consequences of religion (e.g., Barro and McCleary, 2003; McCleary and Barro, 2006; Kuran, 2011) and culture (e.g., Guiso et al., 2006), and more specifically to the growing body of quantitative empirical work on the impact of the Reformation on economic outcomes in Europe. Becker et al. (2016) present a comprehensive review of this literature, discussing studies of the Reformation's effects on human capital acquisition (e.g., Becker and Woessmann, 2008, 2009; Boppart et al., 2013); work ethic (e.g., Basten and Betz, 2013; Spenkuch, 2016); and, economic development (e.g., Becker and Woessmann, 2009; Cantoni, 2015; Dittmar and Meisenzahl, 2016). As Becker et al. (2016) observe, existing work typically studies effects over the long run, with outcomes observed in the 19th, 20th, and even 21st centuries. $^{6}$

Our work complements the existing empirical work on the Reformation by examining its short- and medium-run effects, and focusing on the allocation of resources between religious and secular uses. ${ }^{7}$ Our finding of economic secularization produced by the Reformation not only doc-

\footnotetext{
${ }^{5}$ See Altonji et al. (2012) for a contemporary analysis of how students' college major choices are affected by expectations of future labor market outcomes.

${ }^{6}$ Exceptions include Dittmar and Meisenzahl (2016), who study human capital responses to institutional change in the short run, and Cantoni (2015), who studies consequences for growth in the early modern era.

${ }^{7}$ In examining the impact of religious shocks on the allocation of resources within a society, our work is closely related to that of Chaney $(2008,2013)$, but examining a different context, and exploiting more disaggregated data along multiple margins. Our work on the historical allocation of resources across sectors complements a large contemporary
} 
uments the consequences of a monumental event in European history, but also contributes to the social science literature on the (complicated) relationship between the Reformation and secularization. A long tradition in sociology argued that the Reformation represented a distinct acceleration of the so-called "differentiation" of the religious and the non-religious spheres of society-that is, of secularization (e.g., Saint-Simon, 1975; Berger, 1967; Taylor, 2007). However, the economics of religion literature would suggest that an increase in religious competition-induced by the Reformation—should have increased religiosity (Iannaccone, 1998; Ekelund et al., 2006). Summarizing these positions, Gorski (2000, pp. 158-159) writes:

Most versions of secularization theory ... assume that the breakup of the Western [Catholic] Church diminished the authority and influence of religious elites and institutions. ... One could reasonably argue, and many early-modernists do argue, that the intensity of religious authority actually increased following the Reformation. This is because differentiation-the breakup of the Roman Church and the emergence of the great confessions-was accompanied by de-differentiation-tighter links between church and state and closer cooperation between clergy and laity. ... This raises an important question: If the Reformation led to de-differentiation, how are we to explain the re-differentiation that followed?

Our findings suggest that economic secularization-distinct from cultural, social, or even political secularization-may reconcile views of a Reformed Europe that was both extremely religious, and also on the path toward "re-differentiation" — that is, toward secularization.

In what follows, we first, in Section 2, present a historical overview of the Reformation viewed through a framework linking religion to Europe's political economy and labor markets. Next, in Section 3, we describe the datasets that we constructed to study the Reformation's economic consequences. In Section 4, we document the reallocation of resources between the religious and secular sectors. Finally, in Section 5 we offer concluding thoughts.

\section{Historical background}

We view the Reformation as fundamentally a shock to the market for religion, which had consequences for the political economy and labor markets of Europe. Here we describe these historical processes at work. We provide a brief timeline of the Reformation's major events in Table 1.

\subsection{The Reformation as a shock to the market for religion}

At the start of the 16th century, just prior to the Reformation, the Catholic Church enjoyed a virtual monopoly in the market for religion in Western Europe and extraordinary wealth and power (the

literature on sectoral shocks and the allocation of economic inputs, particularly labor (e.g., Davis and Haltiwanger, 2001; Autor et al., 2016; Charles et al., 2016b,a). 
Table 1: Timeline of Major Reformation Events, 1517-1648

\begin{tabular}{rl}
\hline Date & Event \\
\hline 1517 & Luther posts 95 theses in Wittenberg \\
1521 & Edict of Worms condemns Luther as a heretic \\
1522 & First formal Protestant ordinances passed \\
$1524-1525$ & Great Peasants' War \\
$1546-1547$ & Schmalkaldic War \\
1555 & Peace of Augsburg establishes cuius regio, eius religio principle \\
$1618-1648$ & 30 Years' War \\
\hline
\end{tabular}

foundation stone of St. Peter's Basilica was laid in 1506). In October 1517, Martin Luther posted his famous 95 theses critiquing Church practices. Luther's critiques focused on the corruption of the Catholic Church, particularly the sale of "indulgences," which believers purchased to secure early release from purgatory.

While Luther did not set out to challenge the religious monopoly of the Catholic Church, a clear break between the Church and Luther emerged in 1521, when the Edict of Worms condemned him as a heretic. The emergence of the Protestant Reformation as a movement that challenged the Catholic Church was possible for two reasons: first, Luther and his supporters were able to disseminate their ideas widely, rapidly, and relatively cheaply using the newly invented printing press (Rubin, 2014; Dittmar and Seabold, 2016). Second, politically active laymen adopted and adapted reformist ideas and pressed them on governing elites (Cameron, 1991).

The reformers argued that biblical authority was paramount over and above the authority of existing church institutions, called for moral renewal within cities, and were often anti-clerical and anti-monastic (Moeller, 1972; Dykema and Oberman, 1993). Protestants argued for and began to implement a program that included the abolition of the Catholic rite mass, the establishment of safeguards against church corruption, and increased public goods provision in health and education (Dittmar and Meisenzahl, 2016). The impact of the movement was seen quickly, with the first local ordinances enshrining elements of Protestant ideology in city laws passed in $1522 .{ }^{8}$

The reform movement also inspired more radical action, inflaming the Great Peasants' War of 1524-1525 (Blickle, 1981). A declaration from the period captures the popular spirit of antimonasticism of the time (Cohn, 1979, p. 28):

It is well known and clear to all that everywhere there are too many monasteries, and that they unashamedly claim to be outside the world, and yet together with the large foundations they even bring into their own possession all the goods of the world, in-

\footnotetext{
${ }^{8}$ Cities and urban actors played a central role in the development and diffusion of Reformation ideas and institutions (Moeller, 1972; Dittmar and Meisenzahl, 2016). Cities contained the necessary concentrations of people, levels of literacy, and cultural sophistication to put the ideas of religious reformers on the political agenda in the 1520s (Brady, 1998; Ozment, 1975).
} 
cluding secular lordship, precious objects, money, wine and grain; they are no use or help to anyone, and often sell their grain during dearths at a double price; for this and other reasons we have considered together and decided to tolerate no monastery any longer, but to close them.

\subsection{The Reformation as a political economy shock}

While in the first years after 1517 cities and peasants were the main actors behind the movement to reform the Church, with the territorial lords remaining more cautious, this changed over the course of the 1520s. The Reformation provided an important opening for renegotiating the balance of power between the Catholic Church and secular lords. Our empirical analysis below shows that princes who turned to Protestantism filled the void left by the Church-a near-monopolistic provider of spiritual, educational, and social welfare services-by reallocating physical and human capital to a secular, state-run administration.

Leveraging the anti-monasticism of the Protestant movement to acquire property and power was a natural temptation for secular princes. Ocker (2010, p. 62) writes, "Monasticism is relevant ... for the simple reason that monasteries were landholders, sometimes very great landholders, and hence they fragmented the dominions of the European historian's much-anticipated confessional states." Princes expropriated monasteries in the name of religious duty: "Princes like Philip of Hesse, whose confiscations in 1527 set an early benchmark for evangelical church-plundering, defended their actions as defense of religion, as protecting the church from the malpractice of priests, monks, and nuns" (Ocker, 2010, p. 62; see also Ocker, 2006).

The Reformation provided an opportunity for secular rulers to strengthen their fiscal positions as well. Prior to the Reformation, religious orders enjoyed exemption from taxes and civic duties, monopolies on priced religious services (e.g., funeral services) and on the production of products like beer. Whether in the name of populism or religious duty, many princes saw an opportunity to enhance their political and economic positions as a result of the Reformation. It is worth noting that the shifting of the balance of power was not exclusive to territories that adopted Protestantism: rulers who remained Catholic, too, were able to strike better bargains with the Church under the threat of conversion (Cameron, 1991).

Conflict between princes who adopted Protestantism and those who remained Catholic reached a climax in the 1540s, with the establishment of the Schmalkaldic League of Protestant princes, and the Schmalkaldic War of 1546-1547. While the Protestant princes were defeated in the war, Holy Roman Emperor Charles V was unable to re-establish a single faith across the Empire. In 1555 the Peace of Augsburg was agreed to, setting the rule cuius regio, euis religio (whose rule, his religion), allowing territorial lords to adopt either Catholicism or Lutheranism for their territories. Thus, by the mid-1500s, Protestantism in Germany acquired the geographic distribution it would maintain for several centuries (Brady, 1998, p. 373), though the 30 Years' War of 1618-1648 represented a cataclysmic upheaval a half century after the Peace of Augsburg. 
The new political economic equilibrium was quite different from the old, with secular rulers strengthened, particularly in those territories that adopted Protestantism. The Peace of Augsburg provided, for over half a century, a reliable legal setting that allowed for the implementation of the Reformation and the creation of state churches in the territories that converted. As Luther himself wrote (cited in Brady, 2009, p. 260):

If I, Dr. Martin Luther, had never taught or done anything else than to illuminate secular government or authority and make it attractive, for this one deed the rulers should thank me. ... Since the Apostles' time no theologian or jurist has more splendidly and clearly confirmed, instructed, and comforted the temporal rulers than I, by special divine grace, was able to do.

\subsection{The Reformation as a labor market shock}

The Reformation's direct political economy effects—strengthening secular rulers, weakening the Catholic Church, and instigating a wave of monastery expropriations and closures-had indirect effects on the market for skilled labor. One can think about this in terms of stocks and flows. Regarding stocks, prior to the Reformation, the Catholic Church was Germany's largest employer of university graduates. Among German university students before 1550, over 65 percent of graduates pursued in careers in the Church. Data in Jürgensmeier and Schwerdtfeger (2005-2008) suggest the existence of over 80,000 monks in Germany just prior to the Reformation-over 1\% of the German population at the time-with two thirds of them released into the broader labor market by monastery closure in the decades following 1517.9

Flows of highly skilled labor entering the labor force would likely have been redirected as well. Prior to the Reformation, the most common first occupation among German university graduates was employment as a monk. Monastery closure and shift in economic power away from the Catholic Church reduced labor demand and increased uncertainty in the most important sector of employment for the newly graduated. There was a supply-side effect of the Reformation as well: Ocker (2010, p. 62) writes, "The new faith rebutted the most compelling reason to become a monk or a nun-to save one's soul and the souls of others. This rebuttal coincided with, and surely abetted, widespread attrition in monasteries."

Secular princes' increased power and resources meant that the path from higher education into secular employment was increasingly appealing. An ordinance from Württemberg from 1546 notes that "Men are needed to serve in preaching offices, governments, temporal posts, [and] administrative offices" (Strauss, 1988). Luther himself wrote about the importance of high levels of education for state service: "[The common man should be able to read in German at home.] But to preach, to rule, to judge, ... all arts and languages of the world are not enough" (cited in Seifert, 1996, p. 257).

\footnotetext{
${ }^{9}$ We describe the sources of these data in more detail below, in Section 3.
} 
Reflecting their increased demand for skilled labor, princes provided support for investments in university education. ${ }^{10}$ In 1527 landgrave Philipp of Hesse, after establishing a new university in Marburg, also decided to provide students with stipends, financed through the revenues derived from former Church property (Seifert, 1996, pp. 271-272). Thus, shifts in labor market demand and supply seem to have pushed human capital away from church-sector employment and toward secular employment-we will examine this in further detail below.

\section{Data}

Our analysis is focused on three sets of outcome data: (i) monastery closures across Germany over time; (ii) German university graduates' degrees and careers; and, (iii) construction activity across Germany over time. In this section, we describe the sources from which these data are drawn in turn. We also discuss the corresponding assignment of units of analysis to religious categories. We will assign territories, cities, and/or universities that remained Catholic throughout the period of analysis to the category "Catholic"; similarly, we assign territories, cities, and/or universities that would eventually adopt Protestantism to the category "Protestant."11

\subsection{Monastery presence}

We gather data on 3,094 monasteries described in Jürgensmeier and Schwerdtfeger (2005-2008). For each monastery, we collect data on its precise location, date of foundation, and date of closure, if applicable. ${ }^{12}$ In Figure 2, we present a map of the monasteries open in the German lands of the Holy Roman Empire in the 16th century, highlighting those that closed in the 16th century. We also present the time series pattern of monastery closure in Figure 3.

Our analysis of monasteries, like our study of construction events, is oriented around the over 2,200 towns contained in the Deutsches Städtebuch, an encyclopedic source of information on each German town's history. For every town, we calculate the number of monasteries in existence in 1517 within 25 kilometers, as well as the number and share of these monasteries that were

\footnotetext{
${ }^{10}$ University degrees initially fell dramatically following the Reformation, as students left the universities to follow preachers and join the new religious movements. This can be seen in the degree data presented below, and is discussed in more detail in Seifert (1996). University attendance increased only with the institutionalization of the Reformation in later years, and the formal support provided by princes.

${ }^{11}$ Note that the adoption of Protestantism was almost always an absorbing state.

${ }^{12}$ The data include both monasteries and convents, and we use the term "monasteries" as a short-hand. Closure dates are directly coded from Jürgensmeier and Schwerdtfeger (2005-2008). For over 67 percent of monasteries, Jürgensmeier and Schwerdtfeger (2005-2008) provide information on foundations dates. For the remaining monasteries, we first gather evidence on initial monastery construction by order and location from the Deutsches Städtebuch. We identify the foundation dates of any residual monasteries from territorial archives. For example, for monasteries in Baden-Württemberg we review the databank "Klöster in Baden-Württemberg" maintained by the Landesarchiv BadenWürttemberg (the State Archive) at https ://www .kloester-bw.de/index . php. We then cross-check against individual monastery entries on www. wikipedia. de. In total, we identify foundation dates for 3,085 of 3,094 monasteries.
} 


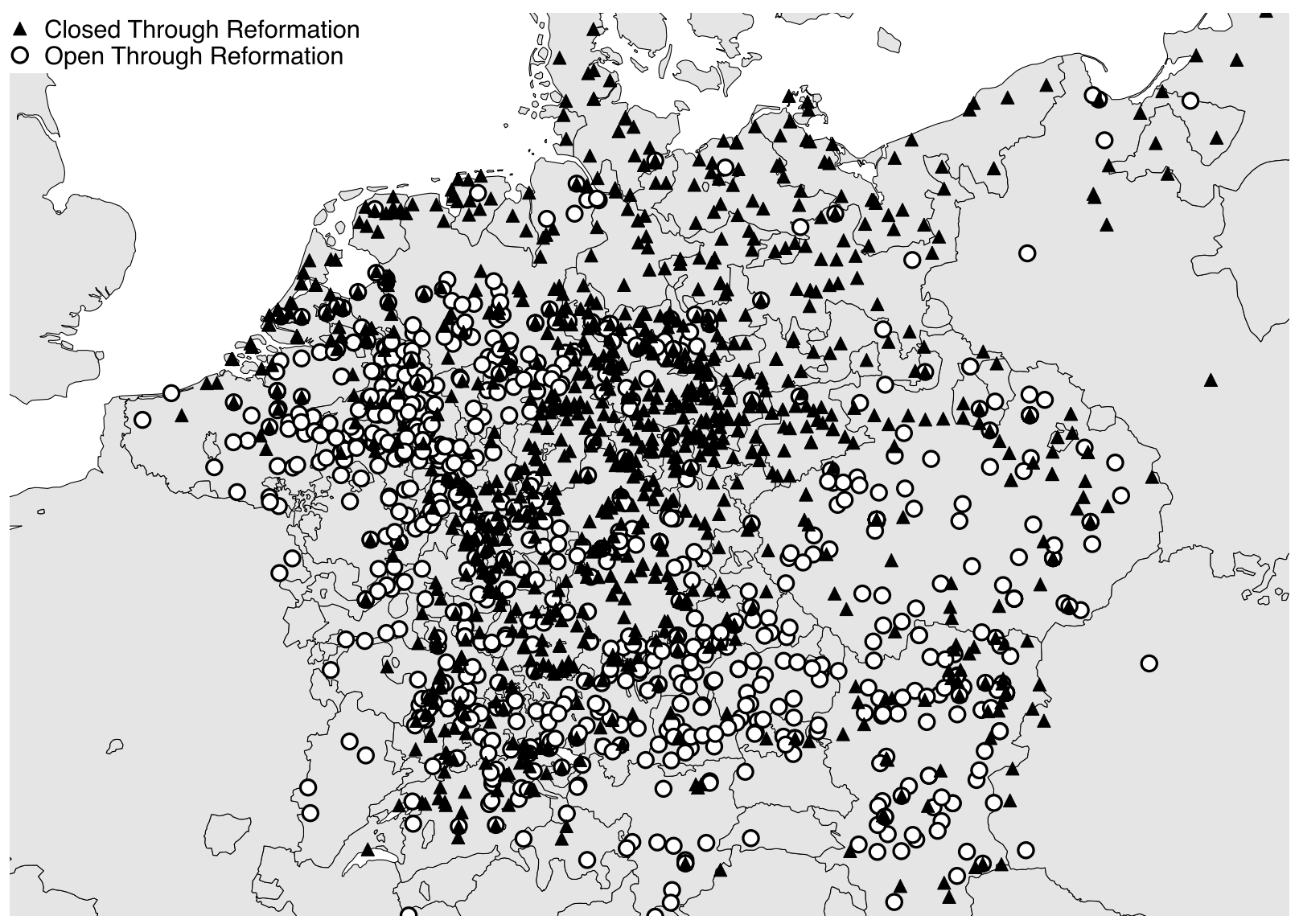

Figure 2: Map of all monasteries in Jürgensmeier and Schwerdtfeger (2005-2008). White circles indicate monasteries that remain open throughout the time period under study. Black triangles indicate monasteries that were opened prior to the Reformation but closed between 1517 and 1600 . Territorial boundaries come from Nüssli (2008).

closed between 1517 and 1600. ${ }^{13}$ To go beyond time-series variation, we exploit cross-sectional variation in territorial religion. We assign each town in the Deutsches Städtebuch to territorial lords following the territorial mapping provided by Nüssli (2008) for the year 1500 and code the religion of territorial lords using Cantoni (2012). ${ }^{14}$ Because not every city can be assigned a religion using this mapping, as a robustness check, we directly code the religion of as many towns as possible using hand-collected evidence from the Deutsches Städtebuch, and find very similar results.

\footnotetext{
${ }^{13}$ Monastery openings were a relatively rare event in the decades around the Reformation: fewer than 100 of the extant monasteries in 1517 were opened in the preceding 30 years.

${ }^{14} \mathrm{~A}$ complete list of territories and their (eventual) religion can be found in the Online Appendix, Table A2.
} 


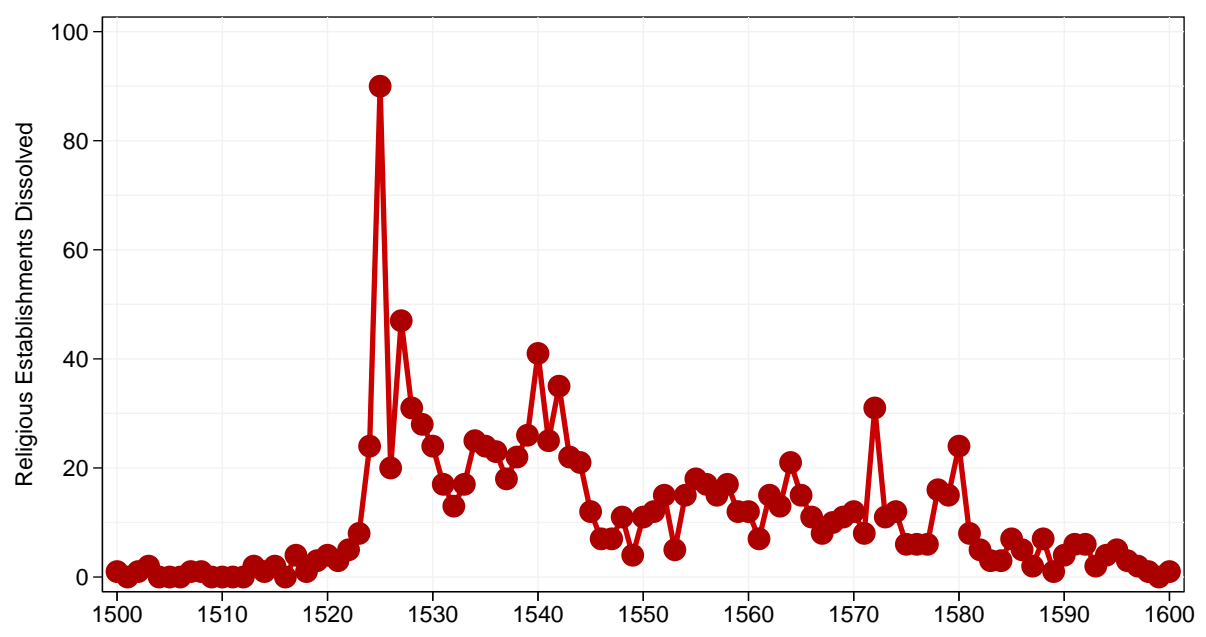

Figure 3: Number of monasteries and convents closing in each year. Closure dates are from Jürgensmeier and Schwerdtfeger (2005-2008).

\subsection{University graduates and their careers}

Our main source of information on German university graduates is the Repertorium Academicum Germanicum (Schwinges and Hesse, 2015), a research program (and online database) developed by historians at the Universities of Berne and Giessen, collecting information on the universe of recipients of academic degrees from German universities until 1550. The German universities are: Basel, Erfurt, Frankfurt (an der Oder), Freiburg, Greifswald, Heidelberg, Ingolstadt, Köln, Leipzig, Mainz, Marburg, Rostock, Trier, Tübingen, Wittenberg, and Würzburg. ${ }^{15}$

Schwinges and Hesse (2015), which we refer to as "RAG" henceforth, collects information on each degree recipient's degree subject(s) and year(s) from university registry sources. The degrees granted include bachelor's degrees, licenses, master's degrees, and doctorate degrees. They were granted by one of the four traditional faculties that all universities of the time featured: arts, law, medicine, and theology. We classify degrees in arts, law, and medicine as "secular" to distinguish them from more church sector-specific training in theology (evidence on career paths associated with degrees in different fields is provided in Section 4.3, below).

To measure post-1550 human capital investments, in particular after the Schmalkaldic War (1546) and the Peace of Augsburg (1555), we hand collect data on university degrees granted by the German universities included in the RAG dataset between 1540 and 1600, consulting Bauch (1897); Erler (1895, 1897, 1909); Eulenburg (1904); Kleineidam (1983); Leinweber (1991); Rüegg

\footnotetext{
${ }^{15}$ Note that we do not consider in our analysis universities attended by Germans outside of the borders of modern Germany, such as Louvain or Prague; nor do we include several small universities opened after 1550, such as Jena. Basel joined the Swiss Confederation only during the period of our study.
} 

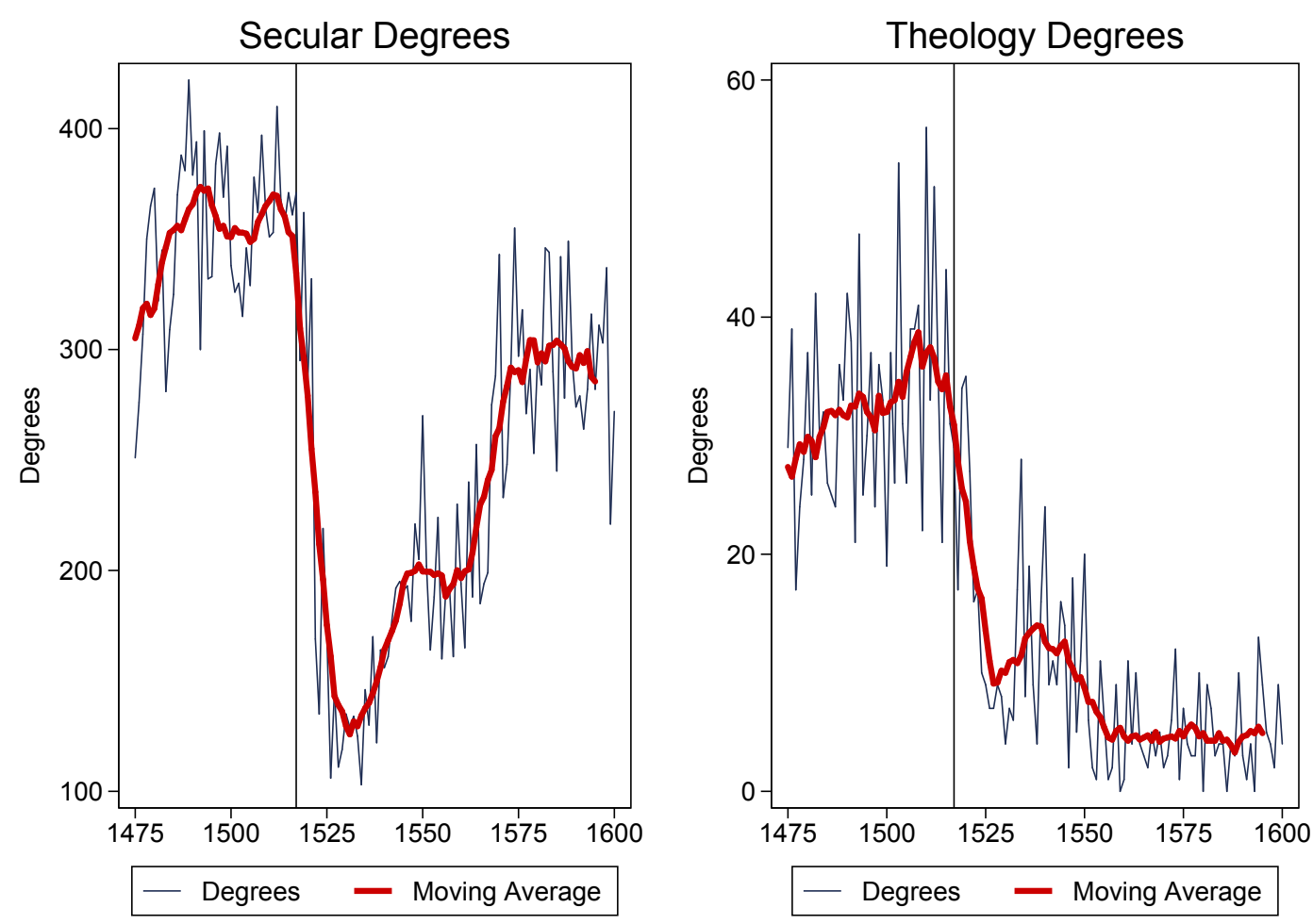

Figure 4: Number of theology and secular degrees granted (yearly data and 11-year moving average). Theology and secular (arts, law, and medicine) degree categories are exhaustive and mutually exclusive. Data come from the Repertorium Academicum Germanicum for degrees granted through 1550 and own data collection (consulting Bauch, 1897; Erler, 1895, 1897, 1909; Eulenburg, 1904; Kleineidam, 1983; Leinweber, 1991; Rüegg, 1996; Steinmeyer, 1912) for degrees granted from 1550 through 1600.

(1996); Steinmeyer (1912). ${ }^{16}$

In Figure 4, we show the number of theology degrees and "secular" degrees over time, from 1475-1600. One can see that after the Reformation, the number of degrees granted falls for all fields initially; the number of secular degrees recovers by the late 1500s, while the level of theology degrees remains low throughout the remainder of the 16 th century. ${ }^{17}$

In addition to information on degrees received, the RAG database contains information on careers for 5,102 of 14,704 students receiving degrees between 1470 and 1550 . The RAG provides over 400 different occupational titles in its database. For example, the top ten occupations in terms

\footnotetext{
${ }^{16}$ We collect data from 1540-1550 in order to compare across data sources using the decade of overlap between 1540 and 1550. Our data and the RAG data closely match. One can see in Online Appendix Figure A1 that the patterns we observe are not at all driven by smoothing across sources.

${ }^{17}$ The numbers of degrees granted by level and by individual subject can be seen in Table A1 in the Online Appendix.
} 


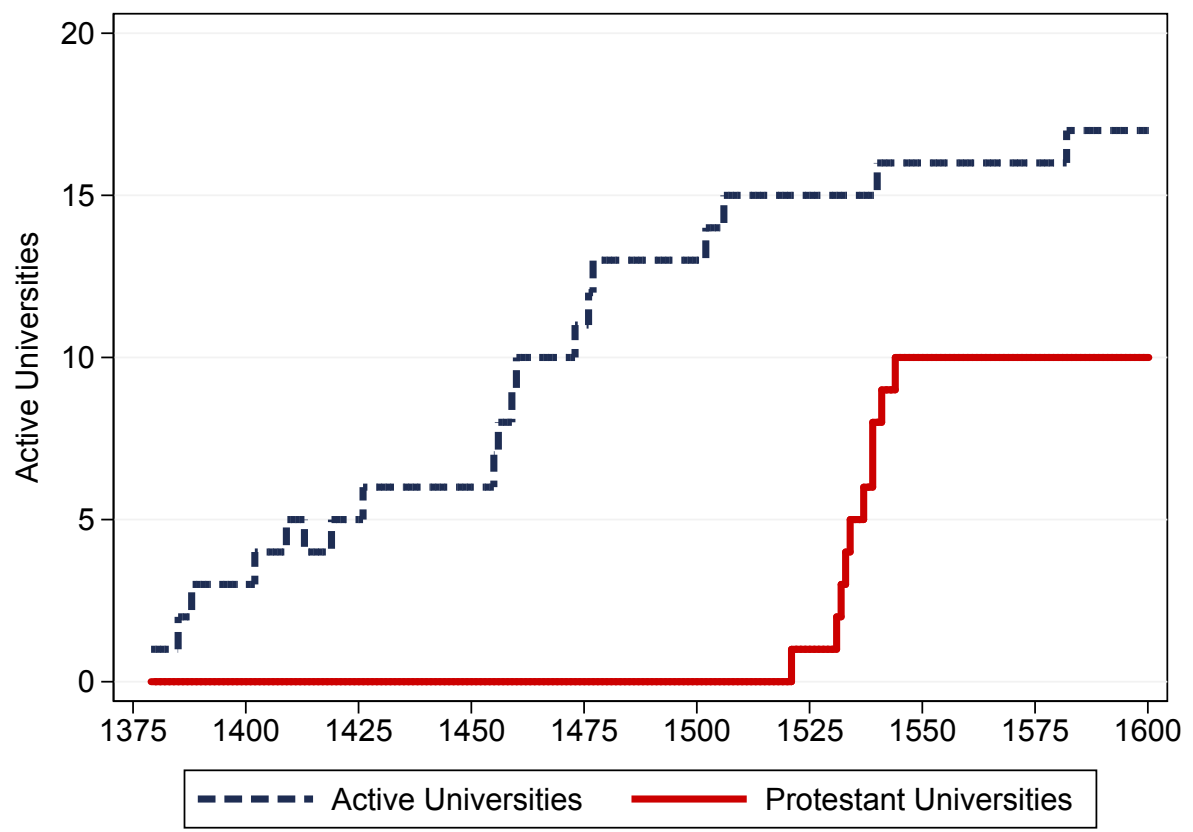

Figure 5: Number of German universities (total/Protestant only) within our sample. Adoption of Protestantism is coded based on Sehling (1902-2013), Spitz (1981), Grendler (2004), and Naragon (2006).

of frequency are: Professor, Kanoniker (Canon), Domherr (Canon, typically receiving a stipend), Dekan (Deacon), Kleriker (Priest), Rektor (Rector), Pfarrer (Pastor, typically at the parish level), Priester (Priest), Mönch (Monk), Propst (Provost or superior). Other occupations include judges, bakers, guild masters, mayors, city councillors, teachers, headmasters, goldsmiths, writers and orators. We divide the occupations into two categories: "church" (including priests, monks, etc.) and "secular" (including professors, judges, mayors, etc.). Many of the occupation titles are archaic; we thus rely on the Thesaurus Professionum Forschungsstelle für Personalschriften (Marburg, 2015), which categorizes historic occupations into seven one-digit categories with subcategories.

Below, we will examine the heterogeneous effects of the Reformation on degrees granted and occupations selected into depending on the denomination of the university at which an individual studied. We rely on Sehling (1902-2013), Spitz (1981), Grendler (2004), Naragon (2006) to identify the universities that adopted Protestantism: Basel, Erfurt, Frankfurt an der Oder, Greifswald, Heidelberg, Leipzig, Marburg, Rostock, Tübingen, and Wittenberg. ${ }^{18}$ In Figure 5 we show the time series of the number of German universities as well as the number that adopted Protestantism. One can see in the figure that there was a sharp increase in the number of Protestant universities

\footnotetext{
${ }^{18}$ Note that Erfurt university became Lutheran in 1521 and returned to Catholicism in 1530s. Thus, we treat Erfurt as a Catholic university.
} 


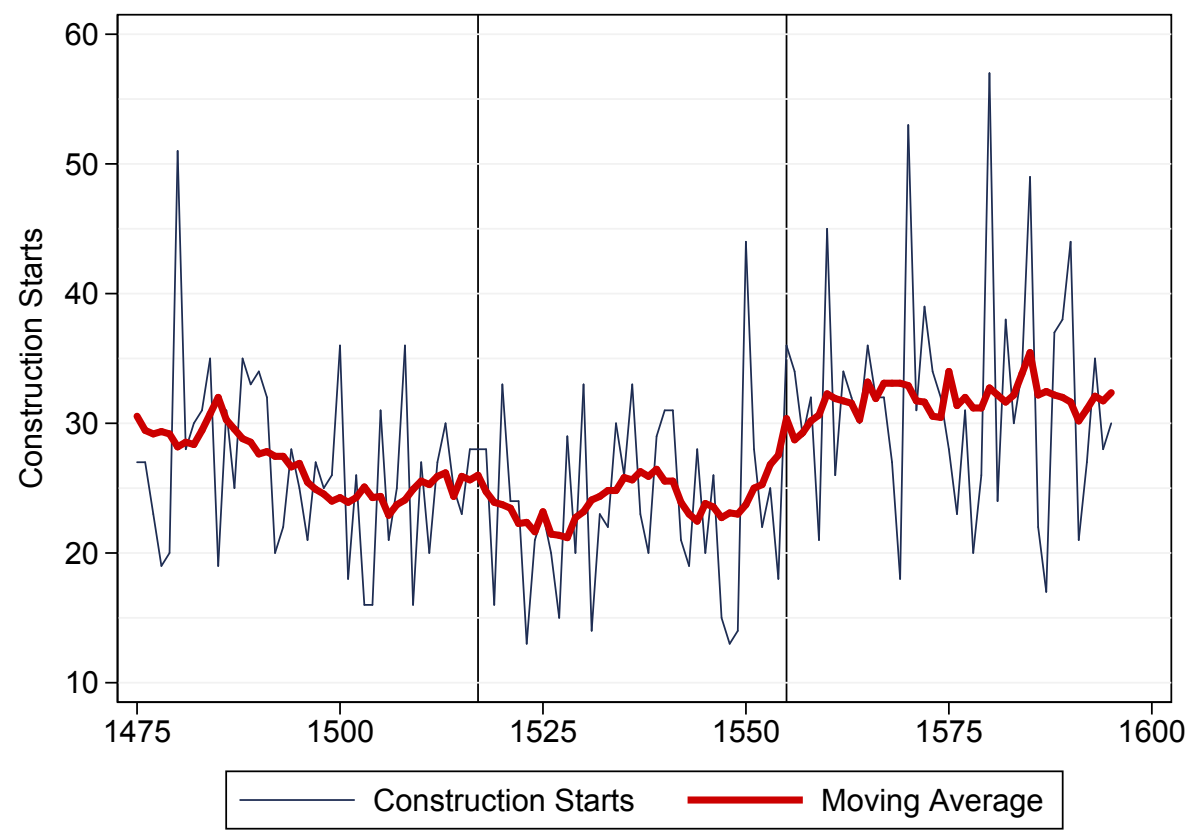

Figure 6: Number of new construction events in Germany (yearly counts and 11-year moving average). Data come from the Deutsches Städtebuch.

between 1520 and $1550 .{ }^{19}$

\subsection{Construction events}

We hand-coded approximately 27,000 unique, major construction "events" at the town level, described in the Deutsches Städtebuch. Each town's entry in the Deutsches Städtebuch includes a section (section 5) titled, "Die Stadt als Siedlung" ("The City as Settlement") within which exists a subcategory (5b) titled, "Markante Gebaude" ("Notable/Important Construction"). We plot the time series of new construction events across Germany (the raw data and an 11-year moving average) between 1475 and 1600 in Figure 6, and one can see an average of 25-35 new events per year. In the figure we mark both the date when Luther posted his 95 theses (1517) and the data of the Peace of Augsburg (1555), which greatly reduced political instability. One can see that following the Peace of Augsburg there was, indeed, an increase in construction activity.

We code each construction event by start date and sector. ${ }^{20}$ We assign the finely detailed con-

\footnotetext{
${ }^{19}$ It is important to note that the adoption of Protestantism was rarely a discrete event, as we treat it here for convenience (see Spitz, 1981 and Seifert, 1996).

${ }^{20}$ Not all construction events are associated with a precise year. For the purposes of our research here, we limit the analysis to those construction events with clearly-specified first years (i.e., "construction starts"). Note, too, that any potential differences in the original collection of data across volumes of the Deutsches Städtebuch will be accounted for in panel regressions with fixed effects.
} 
struction events to into "church construction" (e.g., churches or monasteries) and "secular construction" (e.g., town halls, bridges, malls, palaces, or schools). ${ }^{21}$ Construction events are linked to Protestant or Catholic regions based on the town of the event. We assign towns to lords following the territorial mapping provided by Nüssli (2008) and use information on the religion of territorial lords from Cantoni (2012), as described above.

\section{Empirical evidence on reallocation across sectors}

We now test for changes in the allocation of resources between church and secular uses. We begin by examining the closure of monasteries, which marked the movement of large stocks of land, capital, and human capital away from church uses, and often toward secular lords and administrations. Next, we examine movements in flows of upper tail human capital from church to secular uses. Finally, we examine construction activity, which we see as a sort of "summary statistic" for the allocation of economic inputs toward secular or church purposes.

\subsection{Monastery closure}

Monasteries were ubiquitous in early modern Germany, with the average town having nearly 8 monasteries within 25 kilometers (a single day's walk) on the eve of the Reformation. These monasteries represented an immense stock of land, wealth, and human capital; the expropriation of monasteries following the Reformation thus marked a dramatic shock to the church sector (and the Catholic Church in particular). In most cases, expropriated property was taken by secular authorities.

To provide a sense of the pattern of monastery presence and closure around the time of the Reformation, in Figure 7, we plot the average number of monasteries within 25 kilometers of towns that would become Protestant and towns that would remain Catholic, respectively. One can see in the figure that prior to 1517, the average number of monasteries proximate to towns was quite steady. The number of monasteries near towns that would remain Catholic was somewhat higher than near towns that would become Protestant, a fact that can be explained by the location of Catholic cities-more likely to be in the "older," southern and western parts of the Empire. Importantly, however, trends are very similar in the two sets of towns prior to 1517.

Figure 7 shows that following the posting of Luther's 95 theses in 1517, the density of monasteries declined across Germany, but with important heterogeneity across territories. In towns whose territorial lords eventually adopted Protestantism, there were only three monasteries within 25 kilometers in 1550, and only two in 1600 - this represents a reduction of over two-thirds. In

\footnotetext{
${ }^{21}$ As noted above, we make a sharp distinction between the "church" or religious sector and the secular sector, when in practice there was certainly a grey area between the two. We do believe that our coding is generally accurate; for example, schools served both religious and secular purposes, but as Strauss (1988, p. 193) notes, post-Reformation compulsory schooling laws "placed the supervision of all educational institutions firmly in the hands of princes and magistrates, who were the owners and wielders of the instruments of public power."
} 


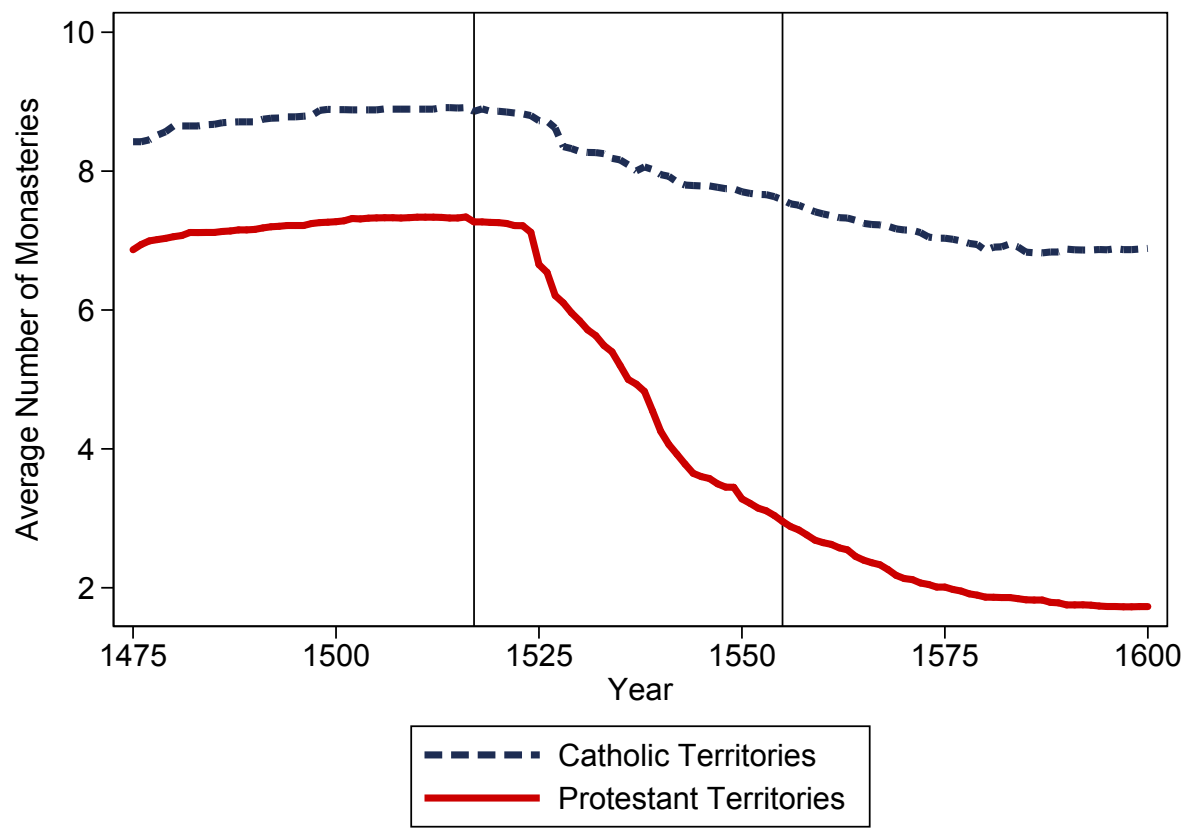

Figure 7: Average number of monasteries within $25 \mathrm{~km}$ of towns included in the Deutsches Städtebuch. Assignment of towns to religious denominations is done by matching each town to its territorial lord identified in the Euratlas for 1500, and using the territorial lord's religion as coded by Cantoni (2012).

towns whose lords remained Catholic, there was a smaller decline in monastery presence, from nine within 25 kilometers in 1517 to around seven in 1600.

In Table 2, we examine these patterns in a regression framework, studying variation across decades in the number of monasteries within 25 kilometers of a town, with the unit of observation the town $\times$ decade. Specifically, we estimate:

$$
\text { monasteries }_{i t}=\alpha_{i}+\delta_{t}+\sum_{\tau=1470}^{1590} \beta_{\tau}\left(\operatorname{prot}_{i} \times \text { decade }_{\tau}\right)+\epsilon_{i t},
$$

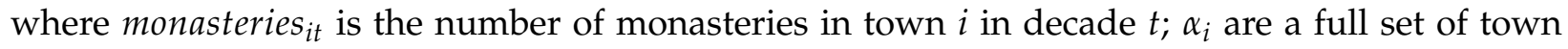
fixed effects; $\delta_{t}$ are a full set of decade fixed effects, and the explanatory variables of interest are the interactions between decade fixed effects and an "eventually Protestant town" dummy variable (1510-1519, just prior to the Reformation, is the omitted reference decade).

In Table 2, column 1, we present coefficient estimates from this baseline specification, and one can see results consistent with Figure 7: prior to 1520, there is no difference in the number of monasteries between eventually Protestant towns and towns that would remain Catholic (even accounting for fixed effects, as in the regression setup). Nor is there is any evidence of a trend 
Table 2: The Effect of the Reformation on Monasteries

\begin{tabular}{|c|c|c|c|c|c|c|}
\hline \multirow[t]{2}{*}{ Dependent variable: } & \multicolumn{6}{|c|}{ Number of monasteries within $25 \mathrm{~km}$ of a town } \\
\hline & $(1)$ & $(2)$ & (3) & $(4)$ & (5) & (6) \\
\hline \multirow[t]{2}{*}{ Protestant $\times 1470$} & 0.06 & 0.06 & 0.06 & 0.18 & 0.01 & 0.09 \\
\hline & $(0.18)$ & $(0.18)$ & $(0.18)$ & $(0.19)$ & $(0.13)$ & $(0.12)$ \\
\hline \multirow{2}{*}{ Protestant $\times 1480$} & 0.02 & 0.02 & 0.02 & 0.06 & 0.00 & 0.03 \\
\hline & $(0.10)$ & $(0.10)$ & $(0.10)$ & $(0.10)$ & $(0.08)$ & $(0.08)$ \\
\hline \multirow[t]{2}{*}{ Protestant $\times 1490$} & 0.01 & 0.01 & 0.01 & 0.01 & 0.01 & 0.01 \\
\hline & $(0.08)$ & $(0.08)$ & $(0.08)$ & $(0.07)$ & $(0.08)$ & $(0.07)$ \\
\hline \multirow[t]{2}{*}{ Protestant $\times 1500$} & 0.01 & 0.01 & 0.01 & -0.00 & 0.01 & 0.00 \\
\hline & $(0.03)$ & $(0.03)$ & $(0.03)$ & $(0.03)$ & $(0.04)$ & $(0.03)$ \\
\hline \multirow[t]{2}{*}{ Protestant $\times 1520$} & -0.36 & -0.36 & -0.35 & -0.15 & -0.42 & -0.26 \\
\hline & $(0.18)$ & $(0.18)$ & $(0.18)$ & $(0.16)$ & $(0.19)$ & $(0.13)$ \\
\hline \multirow[t]{2}{*}{ Protestant $\times 1530$} & -1.32 & -1.33 & -1.31 & -0.75 & -1.54 & -1.13 \\
\hline & $(0.55)$ & $(0.56)$ & $(0.55)$ & $(0.54)$ & $(0.54)$ & $(0.38)$ \\
\hline \multirow[t]{2}{*}{ Protestant $\times 1540$} & -2.51 & -2.53 & -2.49 & -1.59 & -2.85 & -2.16 \\
\hline & $(0.80)$ & $(0.81)$ & $(0.79)$ & $(0.71)$ & $(0.87)$ & $(0.57)$ \\
\hline \multirow[t]{2}{*}{ Protestant $\times 1550$} & -3.01 & -3.03 & -3.00 & -1.98 & -3.41 & -2.66 \\
\hline & $(0.85)$ & $(0.85)$ & $(0.84)$ & $(0.78)$ & $(0.95)$ & $(0.60)$ \\
\hline \multirow[t]{2}{*}{ Protestant $\times 1560$} & -3.26 & -3.28 & -3.26 & -2.10 & -3.73 & -2.91 \\
\hline & $(0.86)$ & $(0.87)$ & $(0.85)$ & $(0.81)$ & $(1.00)$ & $(0.59)$ \\
\hline \multirow[t]{2}{*}{ Protestant $\times 1570$} & -3.45 & -3.47 & -3.45 & -2.16 & -4.00 & -3.12 \\
\hline & $(0.87)$ & $(0.88)$ & $(0.87)$ & $(0.87)$ & $(1.02)$ & $(0.58)$ \\
\hline \multirow[t]{2}{*}{ Protestant $\times 1580$} & -3.45 & -3.48 & -3.46 & -2.12 & -4.03 & -3.14 \\
\hline & $(0.89)$ & $(0.90)$ & $(0.88)$ & $(0.94)$ & $(0.98)$ & $(0.54)$ \\
\hline \multirow[t]{2}{*}{ Protestant $\times 1590$} & -3.55 & -3.58 & -3.56 & -2.21 & -4.15 & -3.27 \\
\hline & $(0.89)$ & $(0.90)$ & $(0.88)$ & $(0.94)$ & $(1.01)$ & $(0.58)$ \\
\hline Observations & 20033 & 20033 & 20033 & 20033 & 20033 & 20033 \\
\hline$R^{2}$ & 0.93 & 0.93 & 0.93 & 0.94 & 0.95 & 0.96 \\
\hline 1400-1470 constr. $\times$ decade FE & $\mathrm{N}$ & Y & $\mathrm{N}$ & $\mathrm{N}$ & $\mathrm{N}$ & $\mathrm{Y}$ \\
\hline 1470 cumul. markets $\times$ decade FE & $\mathrm{N}$ & $\mathrm{N}$ & $\mathrm{Y}$ & $\mathrm{N}$ & $\mathrm{N}$ & $\mathrm{Y}$ \\
\hline 1460-1469 univ. grads $\times$ decade FE & $\mathrm{N}$ & $\mathrm{N}$ & $\mathrm{N}$ & $\mathrm{Y}$ & $\mathrm{N}$ & $\mathrm{Y}$ \\
\hline 1470 monastery stock $\times$ decade FE & $\mathrm{N}$ & $\mathrm{N}$ & $\mathrm{N}$ & $\mathrm{N}$ & $\mathrm{Y}$ & $\mathrm{Y}$ \\
\hline
\end{tabular}

Table presents differential numbers of monasteries within 25 kilometers of a town, comparing towns in territories that would become Protestant and towns in territories that would remain Catholic, by decade (i.e., interactions between an "eventually protestant town" dummy variable and decade fixed effects). The omitted category is Protestant $\times 1510$. The unit of observation is the town $\times$ decade, with the outcome variable calculated as the average number of monasteries open within 25 kilometers of a town in a particular decade. All regressions include town and decade fixed effects. Column 2 includes interactions between the total number of construction events in a town between 1400-1470 and decade fixed effects. Column 3 includes interactions between the cumulative number of market grants in a city as of 1470 and decade fixed effects. Column 4 includes interactions between the total number of students receiving degrees between 1460-1469 from universities within 150 kilometers of a city and decade fixed effects. Column 5 includes interactions between the total number of monasteries within 25 kilometers of a city in the year 1500 and decade fixed effects. Column 6 includes all controls in columns 2-5. Standard errors clustered at the territory level in parentheses ( 35 clusters). Medn of the dependent variable (pre-Reformation): 7.74 . 
toward fewer monasteries near eventually Protestant places, as evidenced by the coefficients relating to the interaction terms of "Protestant" and the pre-1517 decade dummies. One can also see a significant relative decline in monasteries near eventually-Protestant towns following the Reformation. The decline opens in the 1520s, and expands into the late 16th century. The magnitude of the effect, as suggested by Figure 7 is large: beyond the decline in monasteries near Catholic towns, Protestant towns experienced an additional three closed monasteries by the end of the 16th century.

Of course, cities that would become Protestant differed from cities that would remain Catholic along many dimensions. While city-specific, time-invariant characteristics are accounted for by the full set of town fixed effects in the regression, we consider the possibility that post-1520 divergences in the presence of monasteries reflect differences due to city characteristics other than the adoption of Protestantism per se. In Table 2, columns 2 and 3, we examine whether preReformation economic differences may account for part of the post-1520 differential decline in monasteries near eventually-Protestant towns. In column 2, we include as controls interactions between the total number of construction events in a town between 1400 and 1470 and decade fixed effects. These controls have almost no effect on the estimated coefficients on interactions between the decade fixed effects and the "eventually Protestant town" dummy variable. In column 3, we include as controls interactions between the cumulative number of markets granted to a city as of 1470 and decade fixed effects. ${ }^{22}$ Again, our main results are practically unaffected.

Another concern is that pre-existing differences in human capital may have shaped both the evolution of the Reformation and the closure of monasteries in a region. We thus, in Table 2, column 4, control for interactions between decade fixed effects and the total number of students receiving degrees from universities within 150 kilometers of a town in the 1460s (just prior to the start of our analysis). Accounting for human capital differences across towns (and allowing these differences to have decade-varying effects) has some effect on the estimated differences in monastery closure between Protestant and Catholic towns, but we still see a significant divergence following the Reformation, opening up in the 1540s.

A final issue is that the existing monasteries in a region themselves may have shaped both the evolution of the Reformation and the process of monastery closure. In Table 2, column 5, we thus control for the interaction of decade fixed effects and the total number of monasteries within 25 kilometers of a city in the year 1470. One can see that allowing initial stocks of monasteries to have time varying effects on post-Reformation closure of monasteries does not affect our results.

Finally, in Table 2, column 6, we include all of the interactions included in columns 2-5, and our results remain qualitatively unchanged: towns that eventually became Protestant experienced significantly more monastery closure than Catholic towns, even accounting for the time varying effects of initial economic, human capital, and monastery stock differences.

\footnotetext{
${ }^{22}$ The data on market grants to a city come from the Deutsches Städtebuch (see Cantoni and Yuchtman, 2014, for details).
} 
Monastery closure not only represented a direct shift of resources from the Church to secular lords-it was also a massive shock to the early modern high-skilled labor market. With two-thirds of monasteries closing in Protestant territories, a substantial fraction of the most common first job of university graduates-namely, becoming a monk-disappeared in the 16th century. Not only did labor demand in the "religious sector" fall, but labor supply to the religious sector may also have declined-because of increased uncertainty regarding church employment, and because expropriated resources and greater administrative power among secular lords increased the demand for skilled labor in the "secular" sector. We thus turn next to differences in the occupational choices and human capital investments made by highly-skilled workers.

\subsection{Occupational choice}

We begin our analysis of the allocation of highly-skilled labor by examining the choice most directly affected by the Reformation and the consequent expropriation of monasteries: selection by the highly-skilled into becoming a monk. In Figure 8, we plot the share of university graduates in the RAG dataset whose first job is "monk"; we plot one series for individuals whose first university degree was earned at a university that would become Protestant during the Reformation and another series for individuals whose first university degree was earned at a university that would remain Catholic.

One can see in the figure that prior to the Reformation, universities that would become Protestant and those that would remain Catholic produced graduates that selected into becoming monks in similar shares: around 5-10\% of students in both types of universities had first jobs as monks. Immediately after the Reformation, however, graduates of universities that would adopt Protestantism became far less likely to have first jobs as monks, with the share dropping to zero in the 1540s. Among graduates of universities that would remain Catholic, we see no change in the fraction of graduates with first jobs as monks after the Reformation, and if anything the share slightly increases. It is worth noting that there is no evidence that the universities that would become Protestant were trending away from the others: the shares of graduates with first jobs as monks are broadly stable among the two groups of university graduates prior to 1517 (if anything, we observe a slight increase of graduates becoming monks close to 1517 among the universities that would later become Protestant).

We next test for differences in shares of graduates with first jobs as monks across universities, decade by decade, in a regression framework with the unit of analysis the university $\times$ decade. Of interest to us is whether the share of university graduates from universities that would adopt the Protestant religion differentially sort into first jobs as monks. Thus, we regress the share of graduates with first jobs as monks from a given university in a given decade on interactions between an "eventually protestant university" dummy variable and decade fixed effects (the omitted decade 


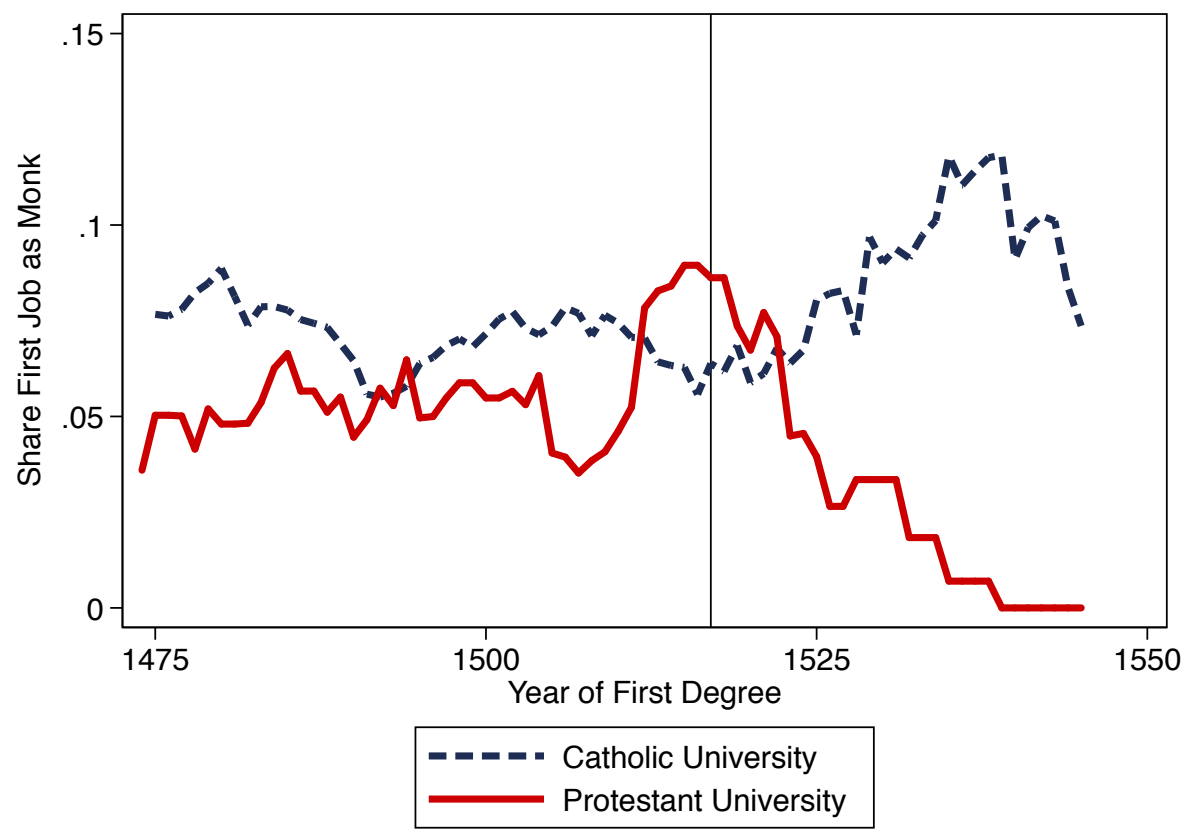

Figure 8: Shares of first job "monk" by (eventual) university denomination. Figure shows the share of first job "monk" among individuals with occupations listed in the Repertorium Academicum Germanicum, by an individual's year of first university degree attainment and by the degree-granting university's eventual denomination (smoothed using an 11-year moving average).

is $1510-1519) .^{23}$

Specifically, we estimate:

$$
\text { share }_{u t}=\alpha_{u}+\delta_{t}+\sum_{\tau=1470}^{1540} \beta_{\tau}\left(\operatorname{prot}_{u} \times \text { decade }_{\tau}\right)+\epsilon_{u t},
$$

where share $_{u t}$ is the share of graduates from university $u$ in decade $t$ whose first occupation indicated in the RAG database is "monk". The $\alpha_{u}$ terms are a full set of university fixed effects; $\delta_{t}$ are a full set of decade fixed effects, and the explanatory variables of interest are the interactions between decade fixed effects and an "eventually Protestant university" dummy variable (1510-1519, just prior to the Reformation, is the omitted reference decade).

We present estimates from this specification in Table 3 . The results in column 1 precisely match what was seen in Figure 8: prior to the Reformation, shares of graduates with first jobs as monks are not following different trends in universities that would eventually become Protestant compared to those that would remain Catholic. However, after the Reformation, particularly in the

\footnotetext{
${ }^{23}$ Because several universities have very small numbers of graduates in particular decades, we weight observations by the number of degrees in a university $\times$ decade cell. Alternatively, we can aggregate data to the "Protestant university" $\times$ decade level and our results are qualitatively identical.
} 
1530s and 1540s, a significantly smaller share of Protestant university graduates have a first job as monks. Moreover, the sum of the post-Reformation interaction coefficients is significantly different from zero ( $p$-value is 0.00 ).

We next attempt to account for differences across universities other than their eventual religious affiliations that might also affect the sorting of their graduates into careers. Because labor market opportunities might vary across space (particularly along the East-West gradient), and differentially so over time (thus affecting labor market outcomes of local university graduates), in column 2 we control for longitude-varying linear time trends. One can see that these controls do not affect our findings. Because newly formed universities might respond differently to the economic, social, and political changes accompanying the Reformation (and because many of the youngest universities in our sample were Protestant), in column 3 we control for university foundation date-varying linear time trends. Again, our results are unaffected. Finally, in column 4, we control for both longitude-varying linear time trends and university foundation date-varying linear time trends, again without significantly affecting our results.

We next broaden our analysis to study selection into first jobs in the entire "church sector"not only monks. As discussed above, one might expect that greater uncertainty of employment in the church sector and greater demand for skilled labor by secular authorities would shift skilled labor toward secular occupations after 1517, particularly in Protestant territories.

In Figure 9, we plot the share of first jobs by sector-church and secular-by year, separately for universities that would adopt Protestantism and for those that would remain Catholic. One can see in the figure that in both types of universities, shares of jobs in the church and secular sectors converged on an even 50-50 split at the time of the Reformation. After the Reformation, the patterns of occupational sorting look distinctly different, with a very clear break in trend toward secular sector first jobs among graduates of Protestant universities, and a slower, smoother continuation of the pre-existing trend toward secular first jobs in Catholic universities. Thus, looking across church- and secular-sector first jobs, we see a shift toward secular sector first jobs after the Reformation, specifically among graduates of Protestant universities.

We can again subject our graphical findings to a more careful regression analysis. In Table 4 replicate the specifications of Table 3, but instead studying selection into any first job in the church sector. One can see that the broad patterns observed for selection into first jobs as monks hold true for more general church-sector employment. Prior to the Reformation, we do not see evidence of differential patterns of first job sector of employment between graduates of universities that would become Protestant and those that would remain Catholic. Coefficient estimates on the interactions between the dummy variable for Protestant universities and decade fixed effects are variable in sign and quite small prior to 1520. After the Reformation, each interaction coefficient is negative, all around $0.10-0.15$, and typically borderline statistically significant. The sum of the post-Reformation coefficients is statistically significantly different from zero at the $5 \%$ or $10 \%$ level across specifications. Broadly, there is a shift away from church-sector first jobs among Protestant 
Table 3: The Effect of the Reformation on the Share of First Jobs as Monks

\begin{tabular}{lcccc}
\hline Dependent variable: & \multicolumn{4}{c}{ Share of first jobs as monks } \\
\cline { 2 - 5 } & $(1)$ & $(2)$ & $(3)$ & $(4)$ \\
\hline Protestant $\times 1470$ & -0.01 & -0.03 & -0.02 & -0.03 \\
& $(0.03)$ & $(0.03)$ & $(0.03)$ & $(0.03)$ \\
Protestant $\times 1480$ & 0.00 & -0.01 & -0.00 & -0.01 \\
& $(0.03)$ & $(0.03)$ & $(0.03)$ & $(0.03)$ \\
Protestant $\times 1490$ & -0.02 & -0.03 & -0.02 & -0.03 \\
& $(0.02)$ & $(0.02)$ & $(0.02)$ & $(0.02)$ \\
Protestant $\times 1500$ & -0.03 & -0.03 & -0.03 & -0.03 \\
& $(0.02)$ & $(0.03)$ & $(0.02)$ & $(0.03)$ \\
Protestant $\times 1520$ & -0.05 & -0.05 & -0.05 & -0.05 \\
& $(0.03)$ & $(0.03)$ & $(0.03)$ & $(0.03)$ \\
Protestant $\times 1530$ & -0.10 & -0.09 & -0.10 & -0.09 \\
& $(0.04)$ & $(0.04)$ & $(0.04)$ & $(0.04)$ \\
Protestant $\times 1540$ & -0.10 & -0.08 & -0.09 & -0.07 \\
& $(0.03)$ & $(0.02)$ & $(0.03)$ & $(0.02)$ \\
\hline Observations & 104 & 104 & 104 & 104 \\
$R^{2}$ & 0.46 & 0.49 & 0.47 & 0.49 \\
$p$-value: sum of $1520-1540$ interactions & 0.00 & 0.00 & 0.00 & 0.00 \\
\hline Longitude $\times$ time & $\mathrm{N}$ & $\mathrm{Y}$ & $\mathrm{N}$ & $\mathrm{Y}$ \\
Univ. foundation date $\times$ time & $\mathrm{N}$ & $\mathrm{N}$ & $\mathrm{Y}$ & $\mathrm{Y}$ \\
\hline
\end{tabular}

Table presents differential first occupational shares as monks between graduates from universities that would become Protestant and graduates from universities that would remain Catholic, by decade (i.e., interactions between an "eventually protestant university" dummy variable and decade fixed effects). The omitted category is Protestant $\times 1510$. The unit of observation is the university $\times$ decade. All regressions weight by the number of degrees in a university $\times$ decade cell. Robust standard errors in parentheses. All columns include decade and university fixed effects. Column 2 controls for linear time trends that vary with the university's longitude; column 3 controls for university foundation date-varying linear time trends; and, column 4 controls for both longitude-varying linear time trends and university foundation date-varying linear time trends. The bottom row of the table presents the $p$ value from a test that the sum of the coefficients on the interactions between the "eventually protestant university" dummy variable and 1520, 1530, and 1540 decade fixed effects equals zero. Mean of the dependent variable (preReformation): 0.06 . 

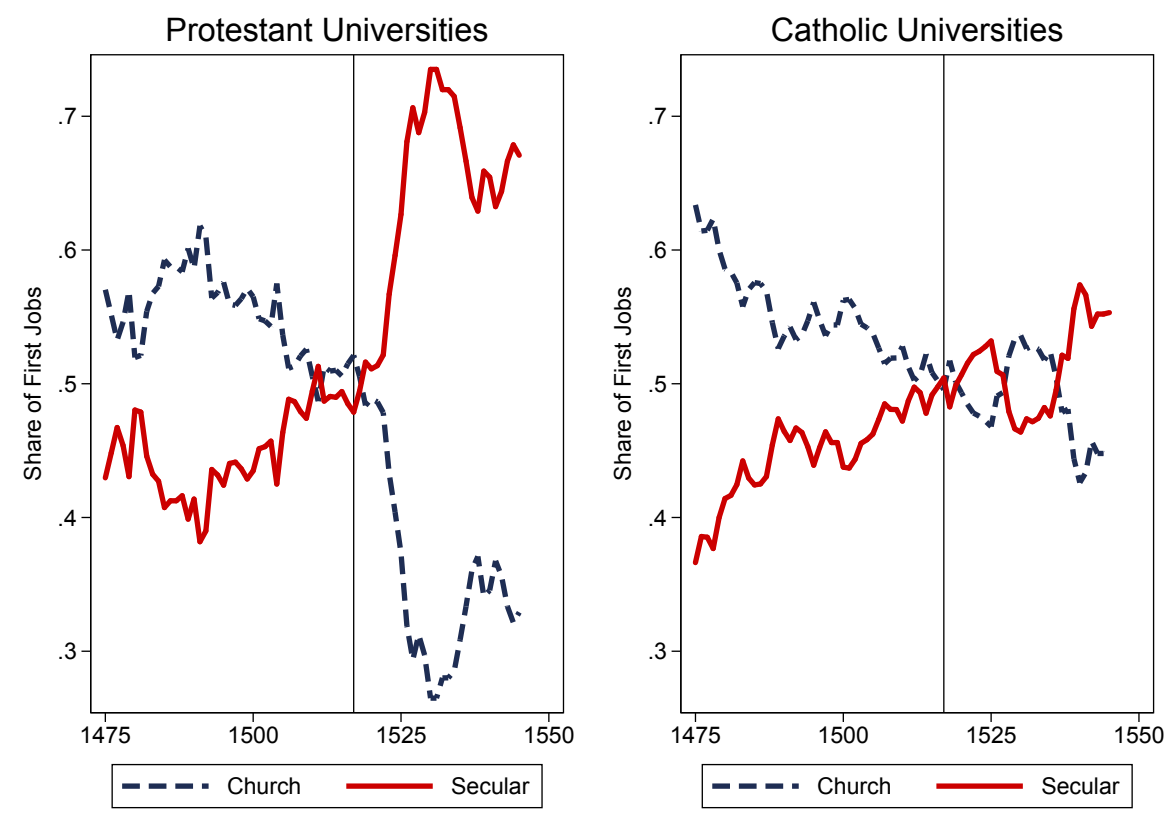

Figure 9: Shares of first job by sector by (eventual) university denomination. Figure shows the share of first jobs in secular and religious economic sectors among individuals with occupations listed in the Repertorium Academicum Germanicum, by an individual's year of first university degree attainment and by the degree-granting university's eventual denomination (smoothed using an 11-year moving average). Occupations are classified into economic sectors using the Thesaurus Professionum (Marburg University, 2015).

university graduates after the Reformation.

\subsection{Investment in Church-specific versus general human capital}

An implication of the reduced employment prospects in the church sector is that forward-looking students should invest less in human capital that specifically has a high payoff in the church sector, and shift their investments toward more general human capital. In fact, while highly-skilled individuals entered church employment from a range of educational backgrounds, there was a particular human capital investment that was essentially church specific: the study of theology. As can be seen in Table 5, while $60 \%$ of students in the RAG database with some career information and without a theology degree had some church sector employment, this number jumps to $88 \%$ among individuals with a theology degree.

We thus examine whether there was not only a shift in employment from the church to the secular sector among the highly skilled following the Reformation, but also a shift in the type of human capital acquired. In Figure 10, we present evidence that this was indeed the case, par- 
Table 4: The Effect of the Reformation on the Share of First Jobs in the Church Sector

\begin{tabular}{lcccc}
\hline Dependent variable: & \multicolumn{4}{c}{ Share of first jobs in the church sector } \\
\cline { 2 - 5 } & $(1)$ & $(2)$ & $(3)$ & $(4)$ \\
\hline Protestant $\times 1470$ & -0.13 & -0.15 & -0.13 & -0.15 \\
Protestant $\times 1480$ & $(0.08)$ & $(0.09)$ & $(0.09)$ & $(0.09)$ \\
& 0.02 & 0.00 & 0.01 & -0.00 \\
Protestant $\times 1490$ & $(0.07)$ & $(0.07)$ & $(0.06)$ & $(0.07)$ \\
& -0.01 & -0.03 & -0.02 & -0.03 \\
Protestant $\times 1500$ & $(0.05)$ & $(0.05)$ & $(0.05)$ & $(0.05)$ \\
& -0.00 & -0.01 & -0.00 & -0.01 \\
Protestant $\times 1520$ & $(0.08)$ & $(0.08)$ & $(0.08)$ & $(0.08)$ \\
& -0.13 & -0.12 & -0.12 & -0.12 \\
Protestant $\times 1530$ & $(0.07)$ & $(0.07)$ & $(0.07)$ & $(0.07)$ \\
& -0.17 & -0.16 & -0.16 & -0.16 \\
Protestant $\times 1540$ & $(0.08)$ & $(0.08)$ & $(0.08)$ & $(0.07)$ \\
& -0.13 & -0.10 & -0.11 & -0.10 \\
& $(0.11)$ & $(0.12)$ & $(0.11)$ & $(0.12)$ \\
\hline Observations & 104 & 104 & 104 & 104 \\
$R^{2}$ & 0.71 & 0.71 & 0.71 & 0.71 \\
$p$-value: sum of 1520-1540 interactions & 0.03 & 0.06 & 0.05 & 0.07 \\
\hline Longitude $\times$ time & $\mathrm{N}$ & $\mathrm{Y}$ & $\mathrm{N}$ & $\mathrm{Y}$ \\
Univ. foundation date $\times$ time & $\mathrm{N}$ & $\mathrm{N}$ & $\mathrm{Y}$ & $\mathrm{Y}$ \\
\hline
\end{tabular}

Table presents differential first occupational shares in church careers between graduates from universities that would become Protestant and graduates from universities that would remain Catholic, by decade (i.e., interactions between an "eventually protestant university" dummy variable and decade fixed effects). The omitted category is Protestant $\times 1510$. The unit of observation is the university $\times$ decade. All regressions weight by the number of degrees in a university $\times$ decade cell. Robust standard errors in parentheses. All columns include decade and university fixed effects. Column 2 controls for linear time trends that vary with the university's longitude; column 3 controls for university foundation date-varying linear time trends; and, column 4 controls for both longitude-varying linear time trends and university foundation date-varying linear time trends. The bottom row of the table presents the $p$-value from a test that the sum of the coefficients on the interactions between the Protestant university dummy variable and 1520, 1530, and 1540 decade fixed effects equals zero. Mean of the dependent variable (pre-Reformation): 0.59 . 
Table 5: The Association Between the Study of Theology and Church-Sector Occupations

\begin{tabular}{lcc}
\hline Type of university graduate & No. of individuals & Fraction with at least one church job \\
\hline At least one theology degree & 906 & $88 \%$ \\
No theology degree & 4,901 & $60 \%$ \\
\hline
\end{tabular}

Table examines the relationship between theology study and careers in the church sector among individuals earning degrees between 1475 and 1550 and who have at least one occupation recorded in the Repertorium Academicum Germanicum dataset. Careers in the church sector are determined using the Thesaurus Professionum (Marburg University, 2015).
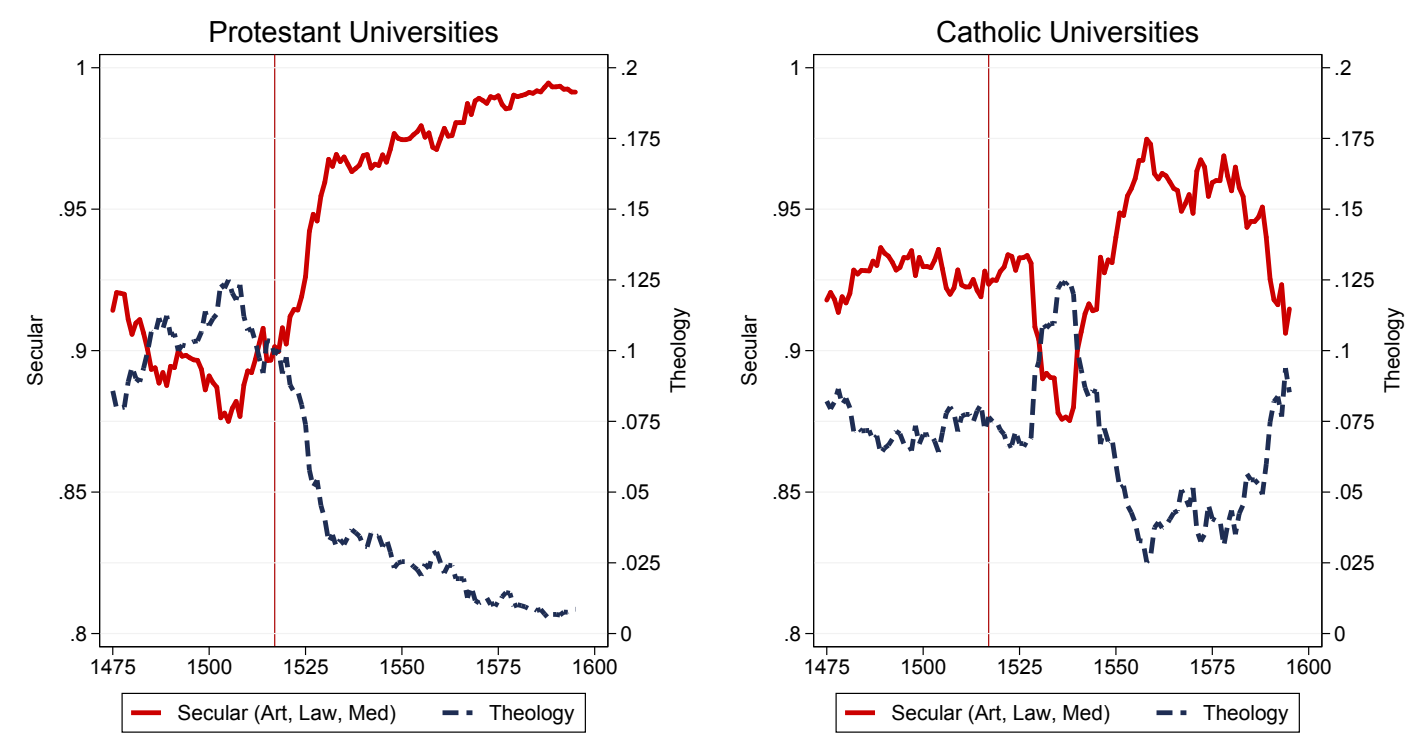

Figure 10: Shares of theology and secular degrees granted by (eventual) university denomination (smoothed using an 11-year moving average). Theology and secular degree categories are exhaustive and mutually exclusive. The secular degree category includes degrees in the arts, law, and medicine. Data come from the Repertorium Academicum Germanicumfor degrees granted through 1550 and own data collection (consulting Bauch, 1897; Erler, 1895, 1897, 1909; Eulenburg, 1904; Kleineidam, 1983; Leinweber, 1991; Rüegg, 1996; Steinmeyer, 1912) for degrees granted from 1550 through 1600. 
ticularly among students at Protestant universities (where we also observed the sharpest shift in occupations). One can see that prior to the Reformation, around 90\% of degrees were awarded in secular fields (art, law, and medicine), while around 10\% were awarded in theology (if anything universities that would become Protestant granted slightly more theology degrees than universities that would remain Catholic). After the Reformation, theology degrees granted fall nearly to zero in Protestant universities. While theology degrees granted fall in Catholic universities as well in the mid-16th century, by 1600, shares of theology degrees granted in Catholic universities are actually greater than they were prior to the Reformation. ${ }^{24}$

We next test for the statistical significance of this divergence in human capital investments, estimating the following model:

$$
\text { degree share }_{u t}=\alpha_{u}+\delta_{t}+\sum_{p=\text { pre,post }} \beta_{p}\left(\operatorname{prot}_{u} \times \text { period }_{s}\right)+\epsilon_{u t} .
$$

The model is very similar to our examination of occupation shares, but instead considers as its outcome the share of degrees in theology among graduates of university $u$ in decade $t$. Another difference is that the explanatory variables of interest are interactions between an "eventually Protestant university dummy" and time period (rather than decade) fixed effects. ${ }^{25}$ The time periods are 1520-1549, i.e., after the start of the Reformation; 1490-1519, the omitted, pre-Reformation baseline period; and, 1470-1489, a "pre-baseline" period allowing us to test for differential preReformation trends in human capital investments between Protestant and Catholic universities. Note that we aggregate decade-level data into longer, time-period-level tests in order to estimate more precise differences in a context with university $\times$ decade cells with very few theology degrees.

In Table 6, column 1, we present the estimated coefficients on the interactions between the "eventually Protestant university dummy" and time period fixed effects. One can see in the table that even controlling for fixed university and decade differences, there is a marginally statistically significant decline in the share of theology degrees in Protestant universities after 1520. One can also see that there was no pre-Reformation difference in human capital investment trends between universities that were eventually Protestant and those that would remain Catholic. In Table 6, columns 2-4, we control for the time varying effects of university characteristics as we did in Tables 3 and 4 . We continue to see evidence of an economically meaningful divergence in human capital investments after the Reformation: a differential fall in Protestant universities of around 5 percentage points relative to a pre-Reformation mean share of theology degrees of $11 \%$. Thus, not only did highly-skilled individuals shift their occupations in response to the Reformation, but they also shifted their human capital investments away from church-sector-specific theology study and

\footnotetext{
${ }^{24}$ Note that these patterns appear within degree levels as well: both examining only bachelor's degrees, or examining only advanced degrees.

${ }^{25}$ We do always control for decade and university fixed effects.
} 
Table 6: The Effect of the Reformation on the Share of Theology Degrees

\begin{tabular}{lcccc}
\hline Dependent variable: & \multicolumn{4}{c}{ Share of degrees in theology } \\
\cline { 2 - 5 } & $(1)$ & $(2)$ & $(3)$ & $(4)$ \\
\hline Protestant $\times$ Pre-1490 & -0.01 & -0.01 & -0.01 & -0.01 \\
& $(0.02)$ & $(0.02)$ & $(0.02)$ & $(0.02)$ \\
Protestant $\times$ Post-1520 & -0.06 & -0.06 & -0.05 & -0.05 \\
& $(0.03)$ & $(0.03)$ & $(0.03)$ & $(0.03)$ \\
\hline Observations & 189 & 189 & 189 & 189 \\
$R^{2}$ & 0.41 & 0.41 & 0.41 & 0.41 \\
\hline Longitude $\times$ time & $\mathrm{N}$ & $\mathrm{Y}$ & $\mathrm{N}$ & $\mathrm{Y}$ \\
Univ. foundation date $\times$ time & $\mathrm{N}$ & $\mathrm{N}$ & $\mathrm{Y}$ & $\mathrm{Y}$ \\
\hline
\end{tabular}

Table presents differential degree shares in theology between universities that would become Protestant and universities that would remain Catholic, across three time periods: 1470-1489, 1490-1519, and 1520-1599. Differential shares are estimated using interactions between an "eventually protestant university" dummy variable and period fixed effects. The omitted period is 1490-1519. The unit of observation is the university $\times$ decade; all regressions weight by the number of degrees in a university $\times$ decade cell. All regressions control for university and decade fixed effects. Column 2 controls for linear time trends that vary with the university's longitude; column 3 controls for university foundation date-varying linear time trends; and, column 4 controls for both longitude-varying linear time trends and university foundation date-varying linear time trends. Robust standard errors in parentheses. Mean of the dependent variable (pre-Reformation): 0.08 .

toward more general human capital.

\subsection{Construction activity}

We view construction activity as approximating a summary statistic for the allocation of economic resources given the requirements of land and financial, human, and physical capital. We begin our analysis of construction activity across church and secular sectors by showing, in Figure 11, new construction events per town per year by sector (church and secular are exhaustive and mutually exclusive categories of construction). We show the time series of construction separately for towns whose territorial lords eventually adopted Protestantism and for towns whose lords remained Catholic. Note that the likelihood of a major construction event is small for a given town $\times$ year observation: on average, German towns had one to two major construction events per century in the early-modern era. 

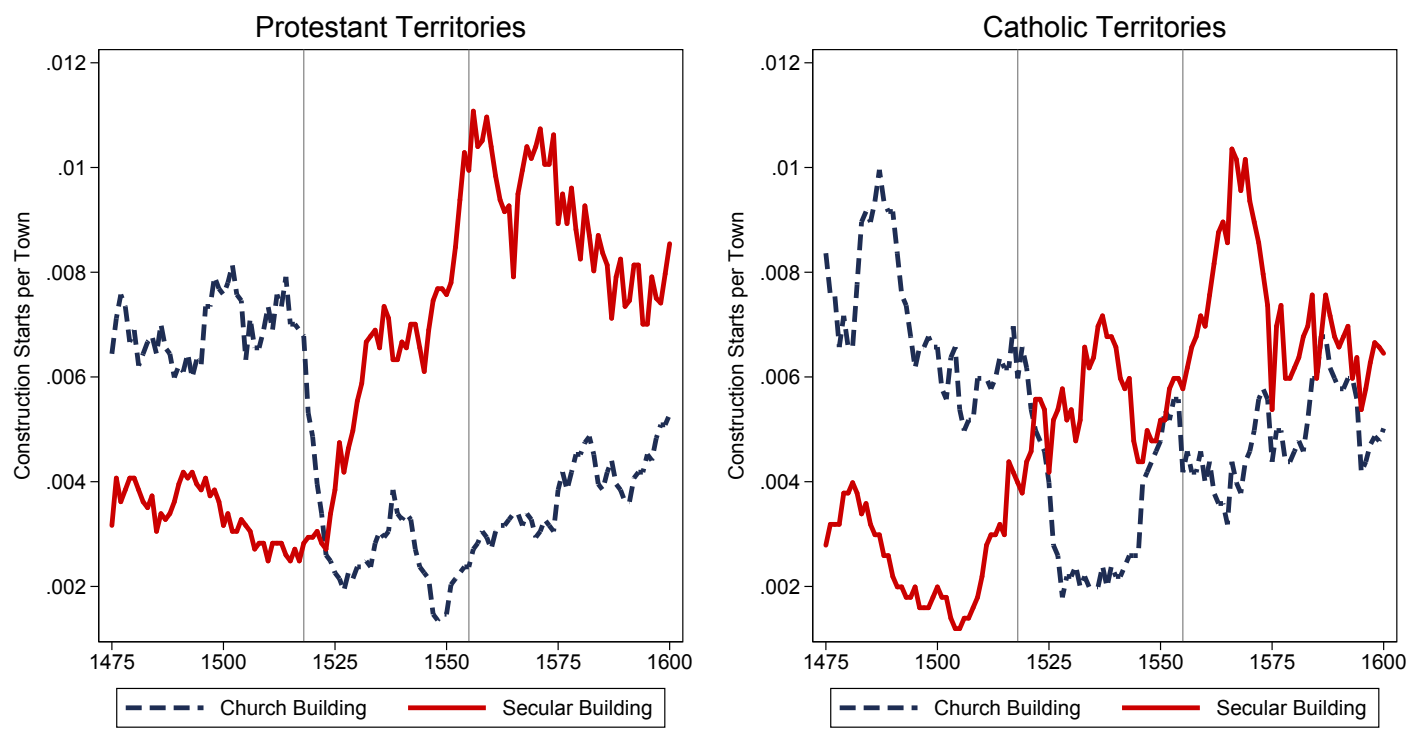

Figure 11: Construction starts disaggregated by sector for towns in (eventually) Protestant and (remaining) Catholic territories (smoothed using an 11-year moving average). Town-level construction data come from the Deutsches Städtebuch. Assignment of towns to religious denominations is done by matching each town to its territorial lord identified in the Euratlas for 1500, and using the territorial lord's religion as coded by Cantoni (2012). 
Several clear facts emerge from Figure 11. First, in both territories adopting Protestantism and those that remained Catholic, church-sector construction predominated prior to the Reformation. Second, in both "eventually Protestant" and "always Catholic" towns, secular construction increased and church construction decreased just after Luther posted his 95 theses in 1517. Third, the shift in resources was much greater and more sustained in regions that adopted Protestantism: by the end of the 16th century, rates of new secular construction were nearly double rates of new church construction in Protestant towns. In Catholic towns, in contrast, church and secular construction were roughly equal at the end of the 16th century.

We next test whether the differences between Catholic and Protestant regions in secular and church sector construction were statistically significant, examining secular and church sector construction at the territory $\times$ decade level. We aggregate our town-level data into larger, territorylevel units in order to more precisely estimate differences in a context in which the vast majority of town $\times$ decade observations have zero construction events.

We estimate the following model:

$$
\text { construction }_{j t}=\alpha_{j}+\delta_{t}+\sum_{d=1470}^{1590} \beta_{d}\left(\text { prot }_{j} \times \text { decade }_{d}\right)+\epsilon_{j t},
$$

where construction ${ }_{j t}$ is a count of the construction events in territory $j$, in decade $t ; \alpha_{j}$ is a set of territory fixed effects; $\delta_{t}$ is a set of decade fixed effects; and the explanatory variables of interest are the interactions between an "eventually protestant territory" dummy variable and decade fixed effects (1510-1519 is the omitted reference decade). Because of the presence of territory $\times$ decade cells with zero total construction, rather than examine the share of total construction in the church sector, we separately predict counts of construction events (construction $\left.{ }_{j t}\right)$ in the church sector and the secular sector.

In Table 7, column 1, we present the estimated coefficients on the interactions between the "eventually Protestant territory" dummy and decade fixed effects in a model predicting church construction events at the territory $\times$ decade level. One can see that prior to the 1520 s, territories that would become Protestant and those that would remain Catholic did not follow different trends in the level of church construction. In contrast, all of the eight post-Reformation interaction terms indicate less church construction in Protestant territories than in Catholic territories (significantly so in the decades following 1520, 1550, 1570, and 1580). We test whether the sum of the post-Reformation coefficients is significantly different from zero, and in the second from the bottom row of the table we present the p-value from this test. Indeed, we find an overall significantly lower level of church sector construction in Protestant territories throughout the 1520-1600 period.

Because the 1520-1550 era was one of political instability and violent conflict (the Peasants' War and the Schmalkaldic War), and because such political instability is particularly likely to affect fixed capital investments like construction, we also test whether the sum of the post-Schmalkaldic 
Table 7: The Effect of the Reformation on Construction Activity

\begin{tabular}{|c|c|c|c|c|}
\hline \multirow[t]{3}{*}{ Dependent variable: } & \multicolumn{4}{|c|}{ Number of construction events } \\
\hline & \multicolumn{2}{|c|}{ Church } & \multicolumn{2}{|c|}{ Secular } \\
\hline & (1) & $(2)$ & (3) & $(4)$ \\
\hline \multirow[t]{2}{*}{ Protestant $\times 1470$} & -1.08 & -1.07 & 0.75 & 0.74 \\
\hline & $(0.78)$ & $(0.81)$ & $(0.61)$ & $(0.59)$ \\
\hline \multirow[t]{2}{*}{ Protestant $\times 1480$} & -1.38 & -1.46 & 0.55 & 0.50 \\
\hline & $(1.00)$ & $(0.95)$ & $(0.42)$ & $(0.40)$ \\
\hline \multirow[t]{2}{*}{ Protestant $\times 1490$} & -0.56 & -0.51 & 1.16 & 1.20 \\
\hline & $(0.75)$ & $(0.74)$ & $(0.57)$ & $(0.55)$ \\
\hline \multirow[t]{2}{*}{ Protestant $\times 1500$} & -0.34 & -0.38 & 1.15 & 1.23 \\
\hline & $(0.69)$ & $(0.70)$ & $(0.41)$ & $(0.38)$ \\
\hline \multirow[t]{2}{*}{ Protestant $\times 1520$} & -2.08 & -1.80 & -0.01 & -0.15 \\
\hline & $(0.85)$ & $(0.60)$ & $(0.66)$ & $(0.58)$ \\
\hline \multirow[t]{2}{*}{ Protestant $\times 1530$} & -0.94 & -0.63 & 1.06 & 0.72 \\
\hline & $(0.90)$ & $(0.61)$ & $(1.16)$ & $(0.95)$ \\
\hline \multirow[t]{2}{*}{ Protestant $\times 1540$} & -1.44 & -1.11 & 1.37 & 1.15 \\
\hline & $(1.08)$ & $(0.81)$ & $(0.92)$ & $(0.73)$ \\
\hline \multirow[t]{2}{*}{ Protestant $\times 1550$} & -2.39 & -2.27 & 3.00 & 2.58 \\
\hline & $(0.97)$ & (1.05) & (1.33) & $(0.97)$ \\
\hline \multirow[t]{2}{*}{ Protestant $\times 1560$} & -1.18 & -0.99 & 1.32 & 0.90 \\
\hline & $(0.84)$ & $(0.76)$ & $(1.23)$ & $(0.85)$ \\
\hline \multirow[t]{2}{*}{ Protestant $\times 1570$} & -1.75 & -1.59 & 2.46 & 2.06 \\
\hline & $(0.87)$ & $(0.83)$ & $(1.22)$ & $(0.87)$ \\
\hline \multirow[t]{2}{*}{ Protestant $\times 1580$} & -1.85 & -1.82 & 2.25 & 1.83 \\
\hline & $(0.79)$ & $(0.83)$ & (1.19) & $(0.79)$ \\
\hline \multirow[t]{2}{*}{ Protestant $\times 1590$} & -1.21 & -1.14 & 1.30 & 1.02 \\
\hline & $(1.01)$ & $(1.10)$ & $(1.12)$ & $(0.92)$ \\
\hline Observations & 455 & 455 & 455 & 455 \\
\hline$R^{2}$ & 0.73 & 0.79 & 0.71 & 0.80 \\
\hline$p$-value: sum of $1520-1590$ interactions & 0.04 & 0.05 & 0.09 & 0.03 \\
\hline$p$-value: sum of $1550-1590$ interactions & 0.05 & 0.07 & 0.07 & 0.02 \\
\hline 1400-1470 constr. $\times$ decade FE & $\mathrm{N}$ & $\mathrm{Y}$ & $\mathrm{N}$ & Y \\
\hline
\end{tabular}

Table presents differential numbers of construction events, by sector, comparing territories that would become Protestant and territories that would remain Catholic across decades (i.e., examining interactions between an "eventually protestant territory" dummy variable and decade fixed effects). The omitted category is Protestant $\times 1510$. The unit of observation is the territory $\times$ decade, with the outcome variable calculated as the sum of construction events in a territory $\times$ decade for a particular sector. The sectors are: church, in columns 1 and 2 and secular, in columns 3 and 4 . All specifications include territory and decade fixed effects. Columns 2 and 4 include interactions between the total number of construction events in a territory between 1400 and 1470 and decade fixed effects. Standard errors clustered at the territory level in parentheses (35 clusters). Means of the dependent variable (pre-Reformation): 3.10 (Church), 1.36 (secular). 
War coefficients is significantly different from zero. In the bottom row of the table we present the p-value from this test. One can see that in the 1550-1600 period of greater stability there remains a significantly reduced level of church construction in Protestant territories compared to Catholic ones.

In Table 7, column 2, we examine whether our results from column 1 were driven by differences between Protestant and Catholic towns in the pre-existing level of construction activity (though the absence of pre-1520 differences in trends is reassuring in that respect). We thus estimate the same specification as in column 1, but control for the interaction between decade fixed effects and the total amount of construction in a town between 1400 and 1470. One can see that including these controls does not meaningfully affect our results.

We also consider the possibility that while the count of church building in Protestant territories shrank after the Reformation, perhaps church building sizes increased. We collect data on church sizes from the 124-volume series Denkmaltopographie Bundesrepublik Deutschland (Dellwing, $1988 / 2011$ ) and its various predecessor series, ${ }^{26}$ which provides us with information on the area of $14 \%$ of the new church buildings we observe in eventually-Protestant territories between 1470 and 1600. We find that church areas increased slightly, but statistically insignificantly from the pre-Reformation era to the post-Reformation era: from around 450 square meters to around 495 in the sample of churches for which we have data (see Online Appendix Table A4).

The decline in church construction following the Reformation, particularly in Protestant territories, raises the question of whether there was there resource destruction or rather reallocation to other types of constructions. In Table 7, columns 3 and 4, we estimate the same specifications as in columns 1 and 2, but examine secular sector construction by town $\times$ decade. One can see in the table that there are were broadly similar trends of secular construction in eventually Protestant territories and territories that would remain Catholic prior to the Reformation. If anything, there is a slight relative decline in secular construction in (eventually) Protestant territories in 1510 (as seen in the positive, significant coefficients on the 1490 and 1500 interactions). Following the Reformation, and particularly during the relative stability of the post-Schmalkaldic War era (1550-1600) one can see a significant relative increase in secular construction in the Protestant territories. That is, following the Reformation, there was significant reallocation of resources away from construction activity for church purposes and toward construction for secular purposes. ${ }^{27}$

\footnotetext{
${ }^{26} \mathrm{~A}$ full set of references is provided in the Online Appendix.

${ }^{27}$ As a robustness exercise, we examine whether our results are primarily driven by large cities. This is particularly interesting given evidence in Dittmar and Meisenzahl (2016) of important institutional changes reflected in school building in Protestant towns. In fact, we find nearly identical results when we estimate the specifications in Table 7, but limited to towns that are too small to appear in the Bairoch et al. (1988) dataset on which many quantitative historical studies rely (see Online Appendix Table A3).
} 


\subsection{Case study evidence}

We finally present evidence from three case studies-the Duchy of Saxony, the Duchy of Württemberg, and the Electorate of Brandenburg-particularly illustrative of the effects of religious variation and the political economy considerations of territorial lords. In each case, the territorial religion was changed following a sharp transfer of power due to unanticipated, plausibly exogenous reasons. ${ }^{28}$ And, in each case, adoption of Protestantism precipitated monastery closure and a reallocation of resources from religious toward secular uses.

The Duchy of Saxony - The Duchy of Saxony was ruled in the early 16th century by Duke Georg, an ardent Catholic. In 1539, Georg's last remaining (Catholic) son, Frederick died. Knowing that his Protestant brother, Heinrich, was in line to inherit the Duchy if he died, Georg attempted to secure the inheritance for the Catholic Ferdinand (who would eventually become Holy Roman Emperor). Georg initiated the legal process necessary to transfer his inheritance Ferdinand; however, before this could be completed, Georg himself died in 1539, thus leading to the accession of Heinrich and the conversion of the Duchy to Lutheranism.

In the top panel of Figure 12, one can see some monastery closure and, as measured by construction events, some shifting of resources away from the church sector following the Reformation even under the Catholic Georg. However, at precisely the moment when the Protestant Heinrich took power (marked by a vertical red line), monastery closure sharply accelerated, and resources were allocated differentially toward secular and away from church uses.

Duchy of Württemberg - In 1519, Duke Ulrich was exiled from the Duchy of Württemberg after killing the husband of his mistress. Control of the Duchy was given to the Catholic future emperor Ferdinand. In 1523, Ulrich adopted the Protestant faith and attempted to retake the Duchy on the back of the Peasants' Revolt, but this attempt failed. One can see that in the first decade after the Reformation, under the Catholic Frederick, there is almost no monastery closure in the Duchy of Württemberg, and very little shifting of construction toward secular purposes.

But in 1534, supported by his friend, the Protestant Philip of Hesse, the Duchy was restored to Ulrich. Immediately thereafter, Ulrich expropriated many of the Duchy's monasteries; by 1535, one-third of the Duchy's farmland was transferred from the monasteries into Ulrich's possession (Ocker, 2010, pp. 55-56). One can see in the middle panel of Figure 12 that exactly at this time secular construction begins to rise and overtakes religious construction in the Duchy.

Electorate of Brandenburg - The Electorate of Brandenburg at the time of the Reformation was ruled by Joachim I (Nestor), who, with his brother Albert, personified the corrupt practices that Luther criticized in his theses. In particular, Joachim I and his Hohenzollern family purchased the archbishopric of Mainz for Albert using loans guaranteed by future sales of indulgences. Be-

\footnotetext{
${ }^{28}$ The potential endogeneity of Protestantism can be articulated along two dimensions: first, territories with particular, possibly time-varying, characteristics might be more likely both to adopt Protestantism and to experience economic secularization. Second, lords with particular characteristics might be more likely both to adopt Protestantism and to pursue economic secularization. Our study of quasi-random variation in territorial lords helps address the former concern, though not the latter.
} 

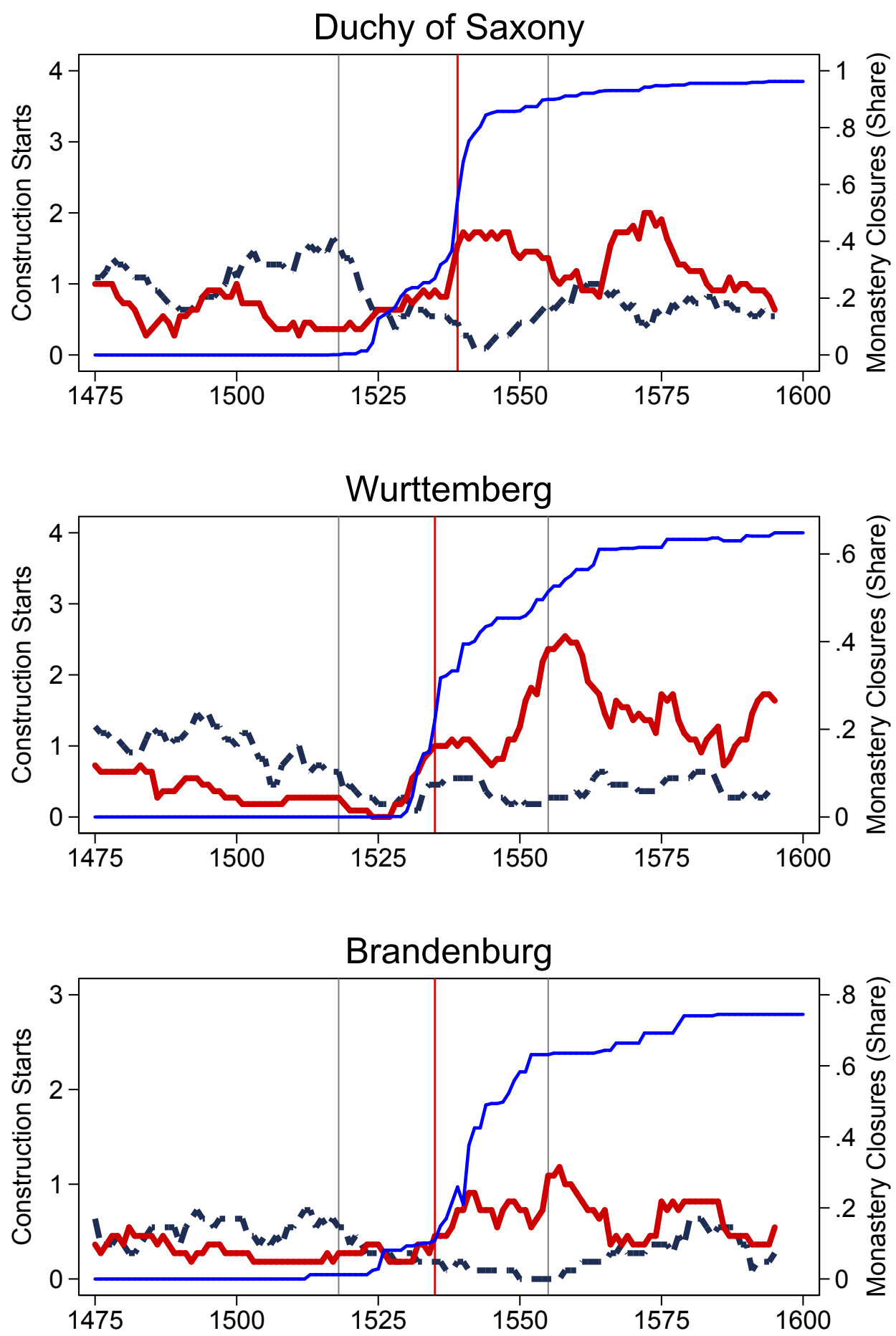

\section{- Church Construction \\ - Secular Construction \\ Monastery Closures}

Figure 12: Monastery closure and construction in three territories: Ducal Saxony, Württemberg, and Brandenburg. Each figure shows the fraction of monasteries closed and the number of construction events in the church and secular sectors (construction events are shown as 11-year moving averages). Red vertical line marks the timing of the change in territorial lord that led to the adoption of Protestantism. 
fitting his staunch Catholicism, Joachim I had his son, Joachim II (Hector) sign an inheritance contract in which Joachim II promised to remain Catholic. One can see in the bottom panel of Figure 12 that during the period of Catholic rule (until the death of Joachim I, in 1535), the Electorate of Brandenburg experienced very few monastery closures and saw very little increase in secular construction.

However, after the death of Joachim I in 1535, Joachim II reneged on his pledge to remain Catholic. In the bottom panel of Figure 12, one can see that shortly after Joachim II took power, the political shock produced a sharp increase in monastery closure, and, as measured by construction activity, a shift of resources toward secular and away from church uses.

\section{Conclusion}

Religious organizations have been among the most economically important institutions in human societies throughout history (Finer, 1999). These organizations historically have accumulated financial capital, possessed land, attracted human capital, and ruled regions. Shocks to the market for religion thus have the potential to affect the underlying structure of economies. We find that the Protestant Reformation marked both a challenge to the incumbent monopolist in the market for religion and a broader economic shock. Not only did the Reformation result in a decline in the economic power of Europe's most powerful institution at the time-the Catholic Church-it also produced a sharp shift in the allocation of economic resources toward secular uses.

Secular lords exploited the ideological shock to the Catholic Church to confiscate monastery resources. Highly skilled labor moved from church careers toward secular careers, including in expanding secular administrations, particularly in regions that adopted the Protestant religion. Consistent with economic theory, university students, anticipating lower and more uncertain returns to church-career-specific training in theology, began to accumulate more general human capital, studying the arts, law, and medicine. The shift in resources toward secular activity was made tangible in the new construction occurring in 16th century Germany, which shifted sharply toward secular purposes, particularly in Protestant regions.

While the Reformation's effects would reverberate across Europe for centuries, and the culmination of Europe's cultural secularization was centuries away, our findings suggest that the first steps toward the rise of a secular West were taken immediately after the Reformation, with the weakening of the Catholic Church and the strengthening of the secular state. 


\section{References}

Altonji, Joseph G., Erica Blom, and Costas Meghir, "Heterogeneity in Human Capital Investments: High School Curriculum, College Major, and Careers," Annual Review of Economics, 2012, 4 (1), 185-223.

Autor, David H., David Dorn, and Gordon H. Hanson, "The China Shock: Learning from LaborMarket Adjustment to Large Changes in Trade," Annual Review of Economics, 2016, 8, 205-240.

Bairoch, Paul, Jean Batou, and Pierre Chèvre, La population des villes européennes, 800-1850: Banque de données et analyse sommaire des résultats, Geneva: Droz, 1988.

Barro, Robert J. and Rachel M. McCleary, "Religion and Economic Growth across Countries," American Sociological Review, October 2003, pp. 760-781.

Basten, Christoph and Frank Betz, "Beyond Work Ethic: Religion, Individual, and Political Preferences," American Economic Journal: Economic Policy, August 2013, 5 (3), 67-91.

Bauch, Gustav, Das älteste Decanatsbuch der philosophischen Facultät an der Universität zu Frankfurt a.O, Breslau: Marcus in Komm., 1897.

Becker, Sascha O. and Ludger Woessmann, "Luther and the Girls: Religious Denomination and the Female Education Gap in 19th Century Prussia," Scandinavian Journal of Economics, December 2008, 110 (4), 777-805.

_ and _ , "Was Weber Wrong? A Human Capital Theory of Protestant Economic History," Quarterly Journal of Economics, May 2009, 124 (2), 531-596.

_, Steven Pfaff, and Jared Rubin, "Causes and Consequences of the Protestant Reformation," forthcoming, Explorations in Economic History, 2016, pp.-.

Berger, Peter, The Sacred Canopy, Anchor, Doubleday, 1967.

Berman, Harold J., Law and Revolution, II: The Impact of the Protestant Reformations on the Western Legal Tradition, Cambridge, Mass. and London: Belknap Press of Harvard University Press, 2003.

Blickle, Peter, The Revolution of 1525: The German Peasants' War from a New Perspective, Baltimore: Johns Hopkins University Press, 1981.

Boppart, Timo, Josef Falkinger, Volker Grossmann, Ulrich Woitek, and Gabriela Wüthrich, "Under Which Conditions Does Religion Affect Educational Outcomes?," Explorations in Economic History, April 2013, 50 (2), 242-266.

Brady, Thomas A., Communities, Politics, and Reformation in Early Modern Europe, Leiden: Brill, 1998.

_, German Histories in the Age of Reformations, 1400-1650, Cambridge: Cambridge University Press, 2009.

Cameron, Euan, The European Reformation, Oxford: Oxford University Press, 1991. 
Cantoni, Davide, "Adopting a New Religion: The Case of Protestantism in 16th Century Germany," Economic Journal, May 2012, 122 (560), 502-531.

- , "The Economic Effects of the Protestant Reformation: Testing the Weber Hypothesis in the German Lands," Journal of the European Economic Association, August 2015, 13 (4), 561-598.

- and Noam Yuchtman, "Medieval Universities, Legal Institutions, and the Commercial Revolution," Quarterly Journal of Economics, May 2014, 129 (2), 823-887.

Chaney, Eric, "Tolerance, Religious Competition and the Rise and Fall of Muslim Science," November 2008. Unpublished, Harvard University.

_ , "Revolt on the Nile: Economic Shocks, Religion, and Political Power," Econometrica, September 2013, 81 (5), 2033-2053.

Charles, Kerwin Kofi, Erik Hurst, and Matthew J. Notowidigdo, "Housing Booms and Busts, Labor Market Opportunities, and College Attendance," November 2016. Unpublished, Northwestern University.

_ , _ , and _ , "The Masking of Declining Manufacturing Employment by the Housing Bubble," Journal of Economic Perspectives, May 2016, 30 (2), 179-200.

Cohn, Henry J., "Anticlericalism in the German Peasants' War 1525," Past and Present, May 1979, 83, 3-31.

Davis, Steven J. and John Haltiwanger, "Sectoral job creation and destruction responses to oil price changes," Journal of Monetary Economics, 2001, 48, 465-512.

Dellwing, H., Denkmaltopographie Bundesrepublik Deutschland, Schwann, 1988/2011.

Dittmar, Jeremiah and Ralf Meisenzahl, "State Capacity and Public Goods: Institutional Change, Human Capital, and Growth in Early Modern Germany," Centre for Economic Performance Paper Series, March 2016, 1418.

- and Skipper Seabold, "Media, Markets, and Radical Ideas: Evidence from the Protestant Reformation," 2016. LSE working paper.

Dykema, Peter A. and Heiko A. Oberman, Anticlericalism: in late medieval and early modern Europe, Leiden: E.J. Brill, 1993.

Ekelund, Robert B., Robert F. Hébert, and Robert D. Tollison, The Marketplace of Christianity, Cambridge, Mass.: MIT Press, 2006.

Erler, Georg, Die Matrikel der Universität Leipzig, Band 1: Die Immatrikulationen von 1410-1599, Leipzig: Giesecke \& Devrient, 1895.

_ , Die Matrikel der Universität Leipzig, Band 2: Die Promotionen von 1410-1599, Leipzig: Giesecke \& Devrient, 1897.

_, Die iüngere Matrikel der Universität Leipzig, Band 1: Die Immatrikulationen vom Wintersemester 1559 bis zum Sommersemester 1634, Leipzig: Giesecke \& Devrient, 1909. 
Eulenburg, Franz, Die Frequenz der deutschen Universitäten von ihrer Gründung bis zur Gegenwart., Leipzig: Teubner, 1904.

Finer, Samuel Edward, The History of Government from the Earliest Times, Oxford: Oxford University Press, 1999.

Gorski, Philip S., "Historicizing the Secularization Debate: Church, State, and Society in Late Medieval and Early Modern Europe, ca. 1300 to 1700," American Sociological Review, February 2000, 65 (1), 138-167.

Grendler, Paul F., "The Universities of the Renaissance and Reformation," Renaissance Quarterly, Spring 2004, 57 (1), 1-42.

Guiso, Luigi, Paola Sapienza, and Luigi Zingales, "People's Opium? Religion and Economic Attitudes," Journal of Monetary Economics, January 2003, 50 (1), 225-282.

_ , , , and _ , "Does Culture Affect Economic Outcomes?," Journal of Economic Perspectives, Spring $2006,20(2), 23-48$.

Iannaccone, Laurence R., "Introduction to the Economics of Religion," Journal of Economic Literature, September 1998, 36 (3), 1465-1495.

Jürgensmeier, Friedhelm and Regina Elisabeth Schwerdtfeger, Orden und Klöster im Zeitalter von Reformation und katholischer Reform, 1500-1700, Münster: Aschendorff, 3 vols., 2005-2008.

Kleineidam, Erich, Universitas studii Erffordensis: Überblick über die Geschichte der Universität Erfurt, Band 3: 1521-1632, Die Zeit der Reformation und Gegenreformation, Leipzig: St.-Benno-Verlag, 1983.

Kuran, Timur, The Long Divergence: How Islamic Law Held Back the Middle East, Princeton, N.J.: Princeton University Press, 2011.

Leinweber, Josef, Verzeichnis der Studierenden in Fulda von 1574 bis 1805, Frankfurt am Main: Knecht, 1991.

Marburg, Universität, “Thesaurus Professionum Forschungsstelle für Personalschriften," http: //www.online.uni-marburg.de/fpmr/thepro/cs.php , 2015.

McCleary, Rachel M. and Robert J. Barro, "Religion and Economy," Journal of Economic Perspectives, Spring 2006, 20 (2), 49-72.

Moeller, Bernd, Imperial Cities and the Reformation, Philadelphia: Fortress Press, 1972.

Mokyr, Joel, The Enlightened Economy: An Economic History of Britain, 1700-1850, New Haven: Yale University Press, 2009.

Murphy, Kevin M., Andrei Shleifer, and Robert W. Vishny, “The Allocation of Talent: Implications for Growth," The Quaterly Journal of Economics, May 1991, 106 (2), 503-530.

Naragon, Steve, "Brief Descriptions of 18th Century German Universities," http://users . manchester.edu/FacStaff/SSNaragon/Kant/universities/UnivBriefHistories.htm , 2006. 
Nüssli, Christos, "Periodical Historical Atlas of Europe," www . euratlas . com , 2008.

Ocker, Christopher, Church Robbers and Reformers in Germany, 1525-1547: Confiscation and Religious Purpose in the Holy Roman Empire, Leiden: Brill, 2006.

- , "The birth of an Empire of Two Churches: church property, theologians, and the League of Schmalkalden," Austrian History Yearbook, 2010, 41, 48-67.

Ozment, Steven E., The Reformation in the Cities: The Appeal of Protestantism to Sixteenth Century Germany and Switzerland, New Haven: Yale University Press, 1975.

_ , The Age of Reform: 1250-1550, New Haven: Yale University Press, 1980.

Rubin, Jared, "Printing and Protestants: An Empirical Test of the Role of Printing in the Reformation," Review of Economics and Statistics, May 2014, 96 (2), 270-286.

Rüegg, Walter, Geschichte der Universität in Europa, Band 2: Von der Reformation zur Französischen Revolution, Munich: C.H. Beck, 1996.

Saint-Simon, Henri de, Selected Writings on Science, Industry, and Social Organization, New York: Holmes and Meier, 1975.

Schwinges, Rainer Christoph and Christian Hesse, "Repertorium Academicum Germanicum," http://www.rag-online.org, 2015.

Sehling, Emil, Die evanglischen Kirchenverordnungen des XVI. Jahrhunderts, Leipzig: O.R. Reisland, 1902-2013.

Seifert, Arno, "Das höhere Schulwesen: Universitäten und Gymnasien," in Nothker Hammerstein, ed., Handbuch der deuschen Bildungsgeschichte, Vol. 1, Munich: C.H. Beck, 1996.

Spenkuch, Jörg L., "The Protestant Ethic and Work: Micro Evidence from Contemporary Germany," May 2016. Unpublished, Northwestern University.

Spitz, Lewis, "The Impact of the Reformation on the Universities," in Leif Grane, ed., Universities in the Reformation: Lectures from the University of Copenhagen Symposium, Leiden: E.J. Brill, 1981.

Squicciarini, Mara P. and Nico Voigtländer, "Human Capital and Industrialization: Evidence from the Age of Enlightenment," Quarterly Journal of Economics, November 2015, 130 (4), 18251883.

Steinmeyer, Elias von, Die Matrikel der Universität Altdorf (1576-1809), Würzburg: Stürtz, 1912.

Strauss, Gerald, "The Social Function of Schools in the Lutheran Reformation in Germany," History of Education Quarterly, Summer 1988, 28 (2), 191-206.

Taylor, Charles, A Secular Age, Cambridge, Mass.: Harvard University Press, 2007.

Weber, Max, "Die protestantische Ethik und der 'Geist' des Kapitalismus," Archiv für Sozialwissenschaften und Sozialpolitik, 1904/05, 20-21, 17-84; 1-110. English Translation: The Protestant Ethic and the Spirit of Capitalism, London: Allen \& Unwin, 1930.

Witte, John, Law and Protestantism: The Legal Teachings of the Lutheran Reformation, Cambridge, UK: Cambridge University Press, 2002. 


\section{Supplementary Appendix - For Online Publication}

\section{Additional references}

The Denkmaltopographie Bundesrepublik Deutschland cited in the main text (Dellwing 1988/2011) was preceded by separate series of volumes listing and describing all historical buildings in the single states of Germany. We looked up sizes of church buildings in these volumes as well, to extend and complement the analysis based on the Denkmaltopographie Bundesrepublik Deutschland.

Die Kunstdenkmäler des Grossherzogtums Baden, 15 volumes, Tübingen: Mohr, 1887-1913.

Die Kunstdenkmäler von Bayern, 112 volumes, München: Oldenbourg, 1892-1972.

Berlin und seine Bauten, 3 volumes, Berlin: Ernst, 1877-1896.

Die Kunstdenkmäler der Provinz Brandenburg, 6 volumes, Berlin: Dt. Kunstverlag, 1907-1921.

Bau- und Kunstdenkmäler des Herzogthums Braunschweig, 5 volumes, Wolfenbüttel: Zwissler, 18961910.

Die Kunstdenkmäler der Provinz Hannover, 26 volumes, Hannover: Provinzialverwaltung, 1899_ 1939.

Kunstdenkmäler im Großherzogthum Hessen, 5 volumes, Darmstadt: Bergstraesser, 1885-1898.

Die Baudenkmäler des Regierungsbezirks Wiesbaden, 6 volumes, Frankfurt am Main: Keller, 19021921.

Die Bau- und Kunstdenkmäler in den Hohenzollern'schen Landen, Stuttgart: Neff, 1896.

Kunst- und Geschichts-Denkmäler des Großherzogthums Mecklenburg-Schwerin, 5 volumes, Schwerin: Bärensprung, 1896-1902.

Kunst- und Geschichts-Denkmäler des Freistaates Mecklenburg-Strelitz, 2 volumes, Neubrandenburg: Brünslow, 1921-1934.

Bau- und Kunstdenkmäler des Herzogtums Oldenburg, 5 volumes, Oldenburg, 1896-1909.

Die Bau- und Kunstdenkmäler der Provinz Ostpreußen, 9 volumes, Königsberg, 1891-1899.

Die Baudenkmale in der Pfalz, Ludwigshafen, 1884-1897.

Bau- und Kunstdenkmäler der Provinz Pommern, 24 volumes, Stettin, 1881-1909. 
Die Kunstdenkmäler der Rheinprovinz, 20 volumes, Düsseldorf, 1891-1937.

Die Kunstdenkmäler der Provinz Sachsen, 33 volumes, Leipzig, 1838-1850.

Denkmalverzeichnis Sachsen-Anhalt, 33 volumes, Halle a. d. Saale, 1879-1923.

Verzeichniss der Kunstdenkmäler der Provinz Schlesien, 6 volumes, Breslau, 1886-1902.

Die Bau- und Kunstdenkmäler der Provinz Schleswig-Holstein, 6 volumes, Kiel, 1887-1925.

Bau- und Kunstdenkmäler Thüringens, 24 volumes, 1888-1928.

Die Bau- und Kunstdenkmäler von Westfalen, 38 volumes, Münster, 1881-1913.

Die Bau- und Kunstdenkmäler der Provinz Westpreußen, 14 volumes, Danzig, 1884-1919.

Die Kunst- und Altertums-Denkmale im Königreich Württemberg, 4 volumes, 1893-1928. 


\section{Appendix figures and tables}
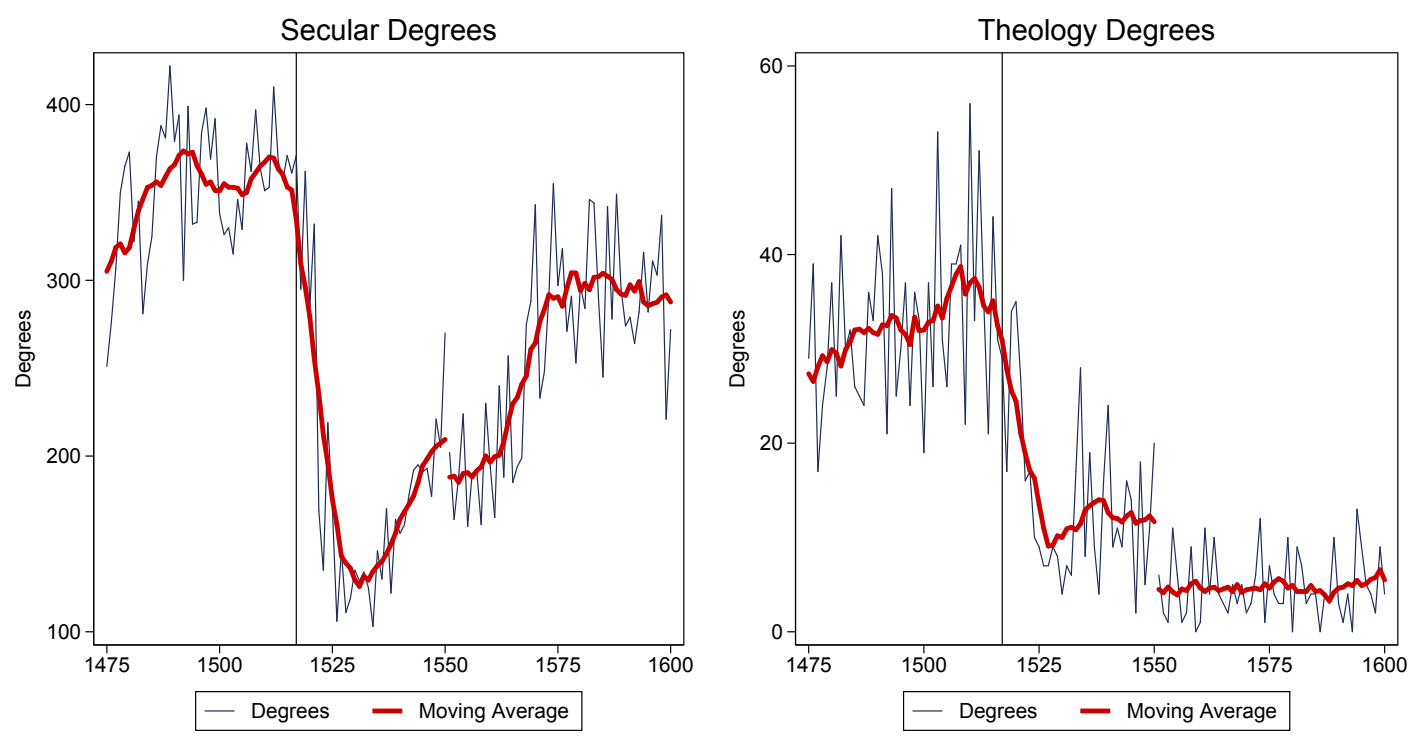

Figure A1: Number of theology and secular degrees granted. Figure shows the number of degrees in theology and in secular subjects by year, and an 11-year moving average. Theology and secular degree categories are exhaustive and mutually exclusive. The secular degree category includes degrees in the arts, law, and medicine. Data come from the Repertorium Academicum Germanicum for degrees granted through 1550 and own data collection (consulting Bauch, 1897; Erler, 1895, 1897, 1909; Eulenburg, 1904; Kleineidam, 1983; Leinweber, 1991; Rüegg, 1996; Steinmeyer, 1912) for degrees granted from 1550 through 1600. This figure differs from Figure 4 in that data are not smoothed across the 1550 breaking point between sources. 
Table A1: Degrees awarded by level and subject

\begin{tabular}{lccccc}
\hline Subject & Bachelor's & License & Master's & Doctor & Total \\
\hline Arts & 17608 & 4163 & 15179 & 450 & 37400 \\
Law & 1210 & 892 & 1 & 896 & 2999 \\
Medicine & 239 & 211 & 7 & 486 & 943 \\
Theology & 2085 & 767 & 38 & 898 & 3788 \\
\hline Across subject total & 21142 & 6033 & 15225 & 2730 & 45130 \\
\hline
\end{tabular}

Data come from the Repertorium Academicum Germanicum. 
Table A2: Territories and assignment to (eventual) religion

\begin{tabular}{lrlr}
\hline Territory & Protestant & Territory & Protestant \\
\hline Anhalt & 1537 & Lorraine & - \\
Baden & 1555 & Mainz & - \\
Bavaria-Landshut & - & Mecklenburg & 1549 \\
Bavaria-Munich & - & Nassau & 1542 \\
Bohemia & - & Palatinate & 1546 \\
Brandenburg & 1539 & Passau & - \\
Brunswick-Calenberg & 1584 & Poland & - \\
Brunswick-Lüneburg & 1529 & Pomerania & 1534 \\
Brunswick-Wolfenbüttel & 1568 & Ruppin & 1539 \\
Burgundian Netherlands & - & Salzburg & - \\
Cleves-Mark & - & Saxony (Ducal) & 1539 \\
Cologne & - & Saxony (Electorate) & 1527 \\
Denmark & 1536 & Small States of the HRE &. \\
East Frisia & 1535 & Swiss Confederacy &. \\
Guelders & - & Trier & - \\
Habsburg Monarchy & - & Upper Palatinate & 1546 \\
Hesse & 1526 & Württemberg & 1534 \\
Jülich-Berg & - & & \\
\hline
\end{tabular}

Table lists territories present in the Euratlas (Nüssli, 2008) for 1500, and their assignment to the territorial lord's (eventual) religion through the dates of introduction of the Reformation as in Cantoni (2012). Note: Cities matched by the Euratlas digital maps to "Small States of the HRE" and to the "Swiss Confederacy" are discarded in our analysis. Territories, and their names, reflect borders as of 1500: Bavaria-Landshut and Bavaria-Munich, e.g., merge after the War of the Succession of Landshut (1503-1505). 
Table A3: The Effect of the Reformation on Construction Activity Outside Large Cities

\begin{tabular}{|c|c|c|c|c|}
\hline \multirow[t]{3}{*}{ Dependent variable: } & \multicolumn{4}{|c|}{ Number of construction events } \\
\hline & \multicolumn{2}{|c|}{ Church } & \multicolumn{2}{|c|}{ Secular } \\
\hline & (1) & (2) & (3) & (4) \\
\hline \multirow[t]{2}{*}{ Protestant $\times 1470$} & -1.10 & -0.94 & 0.57 & 0.56 \\
\hline & $(0.77)$ & $(0.80)$ & $(0.35)$ & $(0.39)$ \\
\hline \multirow[t]{2}{*}{ Protestant $\times 1480$} & $-1.54^{* *}$ & $-1.56^{* *}$ & $0.84^{*}$ & $0.77^{*}$ \\
\hline & $(0.75)$ & $(0.73)$ & $(0.41)$ & $(0.40)$ \\
\hline \multirow{2}{*}{ Protestant $\times 1490$} & -0.89 & -0.75 & $0.88^{*}$ & $0.92^{*}$ \\
\hline & $(0.58)$ & $(0.55)$ & $(0.48)$ & $(0.51)$ \\
\hline \multirow[t]{2}{*}{ Protestant $\times 1500$} & -0.79 & -0.76 & $0.86^{* *}$ & $0.92^{* *}$ \\
\hline & $(0.50)$ & $(0.50)$ & $(0.40)$ & $(0.42)$ \\
\hline \multirow[t]{2}{*}{ Protestant $\times 1520$} & $-1.73^{* *}$ & $-1.39^{* * *}$ & 0.29 & 0.10 \\
\hline & $(0.72)$ & $(0.44)$ & $(0.56)$ & $(0.46)$ \\
\hline \multirow[t]{2}{*}{ Protestant $\times 1530$} & $-1.40^{* *}$ & $-1.08^{* *}$ & 0.98 & 0.58 \\
\hline & $(0.66)$ & $(0.41)$ & $(0.89)$ & $(0.66)$ \\
\hline \multirow[t]{2}{*}{ Protestant $\times 1540$} & $-1.50^{*}$ & $-1.12^{*}$ & 0.92 & 0.76 \\
\hline & $(0.83)$ & $(0.56)$ & $(0.56)$ & $(0.46)$ \\
\hline \multirow[t]{2}{*}{ Protestant $\times 1550$} & $-2.54^{* * *}$ & $-2.33^{* * *}$ & $2.47^{* *}$ & $2.00 * *$ \\
\hline & $(0.74)$ & $(0.73)$ & $(1.06)$ & $(0.76)$ \\
\hline \multirow[t]{2}{*}{ Protestant $\times 1560$} & $-1.57^{* *}$ & $-1.38^{* *}$ & 1.39 & $0.99^{*}$ \\
\hline & $(0.65)$ & $(0.61)$ & $(0.86)$ & $(0.58)$ \\
\hline \multirow[t]{2}{*}{ Protestant $\times 1570$} & $-1.98^{* * *}$ & $-1.80^{* * *}$ & 1.67 & 1.21 \\
\hline & $(0.66)$ & $(0.63)$ & $(1.01)$ & $(0.75)$ \\
\hline \multirow[t]{2}{*}{ Protestant $\times 1580$} & $-1.58^{* *}$ & $-1.54^{* *}$ & 1.58 & 1.10 \\
\hline & $(0.61)$ & $(0.69)$ & $(0.98)$ & $(0.66)$ \\
\hline \multirow[t]{2}{*}{ Protestant $\times 1590$} & -1.30 & -1.29 & 0.97 & 0.63 \\
\hline & $(0.87)$ & $(0.98)$ & $(0.87)$ & $(0.68)$ \\
\hline Observations & 455 & 455 & 455 & 455 \\
\hline$R^{2}$ & 0.70 & 0.76 & 0.67 & 0.78 \\
\hline P-value: sum of $1520-1590$ interactions & 0.01 & 0.01 & 0.08 & 0.05 \\
\hline P-value: sum of $1550-1590$ interactions & 0.01 & 0.02 & 0.07 & 0.05 \\
\hline 1400-1470 constr. $\times$ decade FE & $\mathrm{N}$ & $\mathrm{Y}$ & $\mathrm{N}$ & $\mathrm{Y}$ \\
\hline
\end{tabular}

${ }^{*} p<0.1,{ }^{* *} p<0.05,{ }^{* * *} p<0.01$. Table presents differential numbers of construction events, by sector, comparing territories that would become Protestant and territories that would remain Catholic across decades (i.e., examining interactions between an "eventually protestant territory" dummy variable and decade fixed effects). Sample is limited to towns in the Deutsches Städtebuch too small to be included in the population data collected in Bairoch et al. (1988). The omitted category is Protestant $\times 1510$. The unit of observation is the territory $\times$ decade, with the outcome variable calculated as the sum of construction events in a territory $\times$ decade for a particular sector. The sectors are: church, in columns 1 and 2 and secular, in columns 3 and 4 . All specifications include territory and decade fixed effects. Columns 2 and 4 include interactions between the total number of construction events in a territory between 1400 and 1470 and decade fixed effects.Standard errors clustered at the territory level in parentheses (35 clusters). 
Table A4: The Size of Church Construction Projects in Protestant Territories

\begin{tabular}{|c|c|c|c|c|c|c|c|}
\hline & \multicolumn{3}{|c|}{ Pre: $1470-1517$} & \multicolumn{3}{|c|}{ Post: $1518-1600$} & \multirow{2}{*}{$\begin{array}{c}p \text {-value } \\
\text { diff. in means }\end{array}$} \\
\hline & $\mathrm{n}$ & Mean & SD & $\mathrm{n}$ & Mean & SD & \\
\hline & (1) & $(2)$ & (3) & (4) & (5) & (6) & (7) \\
\hline \multicolumn{8}{|l|}{ All New Church Construction } \\
\hline Indicator: Church Size Recorded & 125 & 0.18 & 0.38 & 88 & 0.08 & 0.27 & 0.03 \\
\hline \multicolumn{8}{|l|}{ Where Church Size is Recorded } \\
\hline Church Size in Square Meters & 22 & 453.24 & 302.43 & 7 & 494.93 & 196.42 & 0.68 \\
\hline
\end{tabular}

This table presents summary statistics on physical sizes of new churches built in German territories that ultimately adopted Protestantism. We study new church construction in cities and towns recorded over the period 1470-1600 in the Deutsches Städtebuch. We obtain data on church sizes by finding each new church in the 124volume series Denkmaltopographie Bundesrepublik Deutschland (Dellwing, 1988/2011), which provides a record of cultural monuments in Germany. The first row provides summary statistics for the binary outcome indicating whether a given church construction event mentioned in the Deutsches Städtebuch is recorded with original floor dimensions in the Denkmaltopographie Bundesrepublik Deutschland $(1=$ 'yes', $0=$ 'no'). The second row provides summary statistics on church sizes for construction events on which the Denkmaltopographie Bundesrepublik Deutschland provides information on the original size of church buildings. Church sizes are measured in square meters, calculated as the sum of the church nave area and church choir area, using data on floor plan widths and lengths. 